\title{
Petrology and geochemistry of the Lyngdal granodiorite (Southern Norway) and the role of fractional crystallisation in the genesis of Proterozoic ferro-potassic A-type granites
}

\author{
Michel Bogaerts ${ }^{\underline{a}}$, Bruno Scaillet $^{\underline{b}}$, Jean-Paul Liégeois ${ }^{\underline{c}}$ and Jacqueline Vander Auwera ${ }^{\underline{a}}$ \\ ${ }^{a}$ L.A. Géologie, Pétrologie et Géochimie (B20), Université de Liège, Sart Tilman, Liege \\ 4000 \\ bISTO-CNRS, $1 \mathrm{~A}$ rue de la Férollerie, 45071, Orléans cédex 2, France \\ ${ }^{\mathrm{c}}$ Isotope Geology, Africa Museum, B-3080, Tervuren, Belgium
}

\begin{abstract}
In south-western Norway, the Sveconorwegian orogenic thickening (1024-970 Ma) is followed by an important post-collisional magmatism (950-930 Ma), divided in two suites (Vander Auwera et al., 2003): the Anorthosite-Mangerite-Charnockite suite (AMC suite) and the Hornblende-Biotite Granitoids suite (HBG suite). The HBG suite displays a continuous trend from gabbronorites to granites.
\end{abstract}

This paper presents the petrography and geochemistry (major and trace elements, $\mathrm{Sr}-\mathrm{Nd}$ isotopes) of the Lyngdal granodiorite and associated massifs (Tranevåg and Red Granite massifs) which belong to the HBG suite, although being very close to the anorthosite massifs. Mafic microgranular enclaves (MME), resulting from magma mingling, can be abundant and probably correspond to the parent magma of the studied plutons. The Lyngdal granodiorite and associated massifs are subalkaline, metaluminous A-type granitoids with high $\mathrm{FeO}_{\mathrm{t}} /\left(\mathrm{FeO}_{\mathrm{t}}+\mathrm{MgO}\right)$ ratio and $\mathrm{K}_{2} \mathrm{O}$ content, forming a ferro-potassic A-type continuous trend from quartz monzodiorite to granite $\left(56-72 \mathrm{wt} . \% \mathrm{SiO}_{2}\right)$. In Harker diagrams, the LyngdalTranevåg plutons share the Proterozoic rapakivi granites trend that they extend to lower $\mathrm{SiO}_{2}$ content. Major and trace element modelling, as well as $\mathrm{Sr}-\mathrm{Nd}$ isotopes, show that fractional crystallisation - without assimilation - is the differentiation process for Lyngdal-Tranevåg. Fractionating minerals are clinopyroxene, hornblende, plagioclase, oxides, biotite, apatite, zircon and allanite. The Red Granite $\left(71-75 \mathrm{wt} . \% \mathrm{SiO}_{2}\right)$ does not belong to this trend probably due to a different initial magma composition.

This study shows that ferro-potassic A-type granitoids can be derived by fractional crystallisation from mafic magmas.

Author Keywords : Norway; Sveconorwegian; Post-collisional; A-type; Granitoids; Liquid line of descent

\section{Introduction}

High-K and high $\left[\mathrm{FeO}_{\mathrm{t}} /\left(\mathrm{FeO}_{\mathrm{t}}+\mathrm{MgO}\right)\right]$ granitoids witness a major crustal process during the Proterozoic. They are mainly metaluminous to weakly peraluminous A-type granites and are often associated with anorthosites and related rocks (Emslie, 1991). Classical occurrences are 
the Finnish rapakivi granites ( Haapala and Ramo, 1990 and Ramo and Haapala, 1995), the Wolf River batholith of Wisconsin ( Anderson and Cullers, 1978), the Nain Complex (Emslie and Stirling, 1993 and Emslie et al., 1994) and the Sherman batholith associated with the Laramie Anorthosite Complex ( Frost and Frost, 1997 and Frost et al., 1999). These granitoids commonly exhibit the rapakivi texture, at least in some part of the intrusions, and thus are rapakivi granites following the definition of Haapala and Rämö (1992). These massifs have low $f \mathrm{O}_{2}\left(f \mathrm{O}_{2}<\mathrm{FMQ}\right)$ and have been referred as 'reduced rapakivi-type granites' by Frost and Frost (1997). Anderson and coauthors ( Anderson, 1983; Anderson and Bender, 1989 and Anderson and Morrison, 1992) divide the metaluminous Proterozoic A-type granites of North America in two series: the ilmenite-series and the magnetite series, underlying their variability in $f \mathrm{O}_{2}$. Granitoids associated with anorthosite massifs are classified in the ilmenite-series (Frost \& Frost, 1997). Above-mentioned authors argue for a low-water content of these granitoids on the basis of the paucity of pegmatites and of the late crystallisation of the hydrous minerals. Recently, however, Dall'Agnol et al. (1999b) have shown that some metaluminous A-type magmas can be quite oxidised and $\mathrm{H}_{2} \mathrm{O}$-rich, with estimated initial water content between 4.5 and $6.5 \mathrm{wt} . \%$ for the Jamon Granite during emplacement in upper crust. This granite has been linked to the rapakivi group by Dall'Agnol et al. (1999a) on the basis of geochemical arguments.

In Southern Norway, an important magmatism occurred at ca. 950-930 Ma and is divided in two suites by Vander Auwera et al. (2003): an anhydrous suite i.e. Anorthosite-MangeriteCharnockite suite (AMC suite) and a suite of metaluminous A-type granitoids with hornblende and biotite i.e. Hornblende-Biotite Granitoids suite (HBG suite). This region is of particular interest as anorthosite massifs and associated granitoids outcrop on large areas and have preserved their magmatic paragenesis (no metamorphic overprint and alteration). The AMC suite has already been the subject of a considerable attention (e.g. Longhi et al., 1999 and references therein) but modern data are lacking for the HBG suite. The present study focuses on the Lyngdal granodiorite and associated plutons (Tranevåg and the Red Granite), which belongs to the HBG suite and presents new data (major and trace elements and $\mathrm{Sr}-\mathrm{Nd}$ isotopic data). The Lyngdal granodiorite is a huge massif (ca. $300 \mathrm{~km}^{2}$ ) that, together with small granitoid bodies (the Tranevåg massif and the Red Granite), forms the southernmost outcropping massifs of the HBG suite (Fig. 1). Among the whole HBG suite, Lyngdal is also the geographically closest massif to the anorthosites. The aim of this paper is to characterise the Lyngdal granodiorite and its associated plutons, to discuss their origin, and to compare these plutons to other hornblende-biotite granitoids (including the rapakivi granites) associated with anorthosites. 


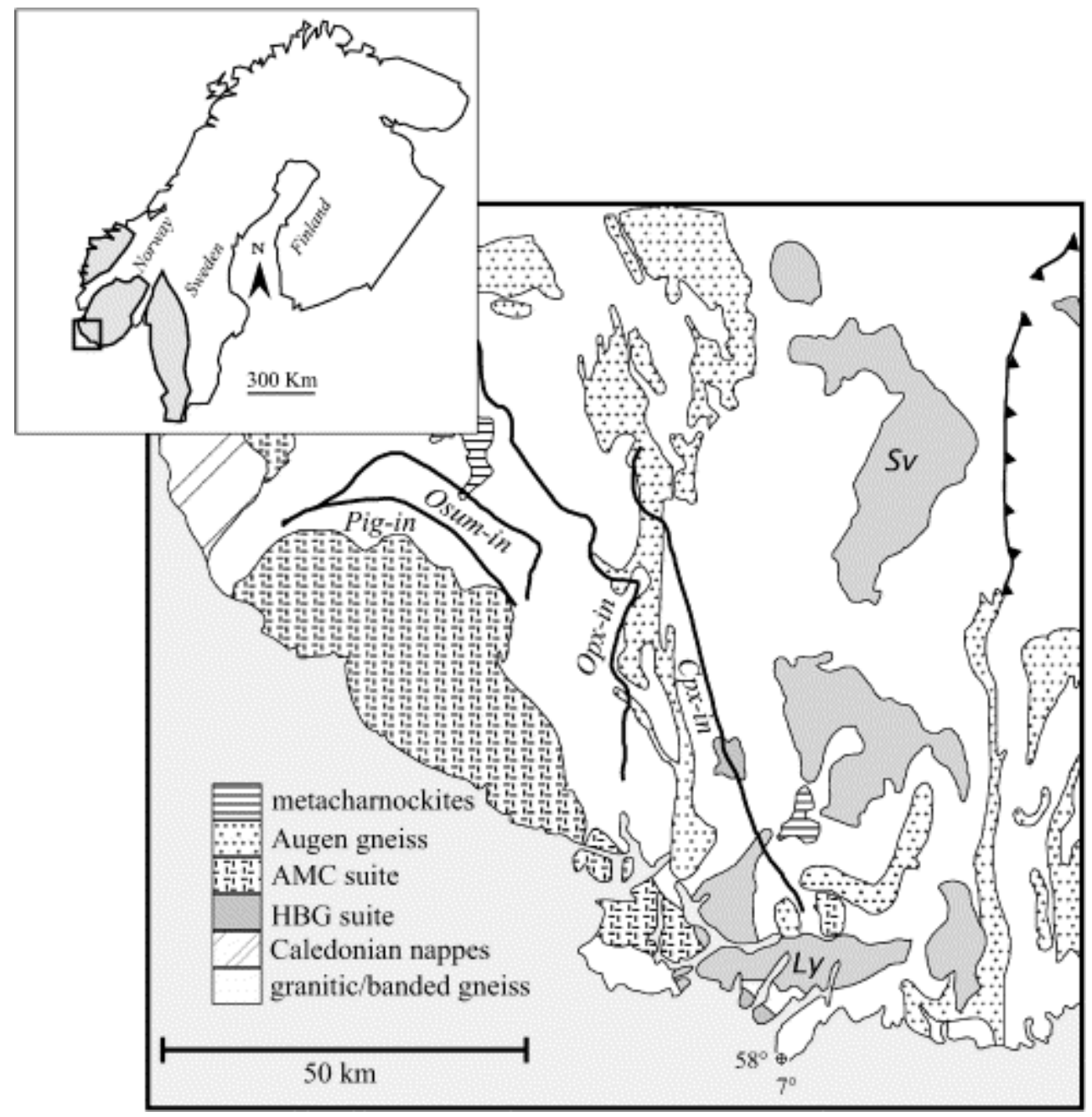

Fig. 1. Schematic geological map of the south-western part of the Sveconorwegian orogen (see inset for the area of the Sveconorwegian orogen, in grey, covered by the figure) simplified from Falkum (1982). Pig-in (pigeonitein), Osum-in (osumilite-in), Opx-in (orthopyroxene-in) and Cpx-in (clinopyroxene-in): see Bingen and van Breemen (1998b) for complete references. Ly: Lyngdal, Sv: Svöfjell.

\section{Geological setting}

The Sveconorwegian province forms the south-western part of the Baltic shield (inset of Fig. 1) and is the result of two important orogenies: the Gothian orogeny (1750-1500 Ma) and the Sveconorwegian orogeny $(1250-950 \mathrm{Ma})$. This province is made up of several terranes (Bingen et al., 2001) separated by major North-South faults and shear zones. In the RogalandVest Agder sector, the regional metamorphic phase linked to the Sveconorwegian orogenic thickening is dated at 1024-970 Ma by U-Pb on monazite (Bingen and van Breemen, 1998b) and reached granulitic facies ( Bingen and Stein, 2001) in the west of the Rogaland-Vest Agder (Opx-in isograd). This phase of regional metamorphism shortly follows an important syn-kinematic calc-alkaline magmatism dated at $1050^{+2 /-8} \mathrm{Ma}$ (U-Pb on zircon) in the Rogaland-Vest Agder sector (Bingen and van Breemen, 1998a). A high-temperature/lowpressure static metamorphism in granulitic facies is dated at 930-925 Ma (Bingen and van Breemen, 1998b). This metamorphism is linked to the emplacement of the Rogaland anorthositic complex (931 \pm 2 Ma: Schärer et al., 1996) and is well marked by the osumilite-in 
and pigeonite-in isograds wrapping the magmatic complex ( Fig. 1). A temperature of 850$800{ }^{\circ} \mathrm{C}$ and a pressure of $5.5 \mathrm{kbar}$ west of the osumilite-in isograd were estimated by Jansen et

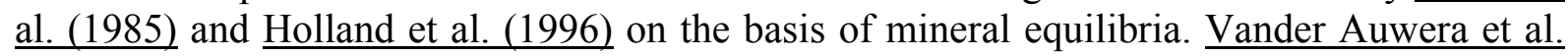
$(1998 b)$ have shown that the pyroxene composition obtained from experiments on a jotunite, constrains pressure of emplacement to be lower than $5 \mathrm{kbar}$, in agreement with estimates of the pressure of crystallisation of the Bjerkreim-Sokndal intrusion (Vander Auwera and Longhi, 1994).

An important late hornblende-biotite granite (HBG) event is temporally and spatially associated with the Rogaland AMC complex. This HBG suite is dominated in Vest Agder by large plutons (e.g. Lyngdal and Svöfjell intrusions, Fig. 1) stretching along the MandalUstaoset Line ( Vander Auwera et al., 2003). This magmatism is considered to be postcollisional because it post-dates the collisional tectono-metamorphic event by some tens of million years, but is still linked to the convergence process ( Liégeois, 1998) as shown for instance by its emplacement controlled by orogenic structures ( Duchesne et al., 1999).

\section{Field relationships, petrography and mineral chemistry}

\subsection{Field relationships}

The Lyngdal granodiorite (Fig. 2) and the associated granitoids (Tranevåg and the Red Granite) commonly display a syn-magmatic foliation well shown by the mafic minerals. This foliation can be concordant or have a sharp contact with the foliation of the gneissic countryrocks (Falkum et al., 1979). The latter can be homogeneous granitic gneisses, often migmatitic banded gneisses with alternating mafic (amphibolites/norites) and quartzofeldspathic layers ( Falkum et al., 1979 and Falkum, 1982) and augen gneisses. The protoliths of these augen gneisses are calc-alkaline granitoids emplaced syntectonically during the Sveconorwegian orogeny at $1050^{+2 /-8}$ Ma (Bingen, 1989 and Bingen and van Breemen, $\underline{1998 b})$. 


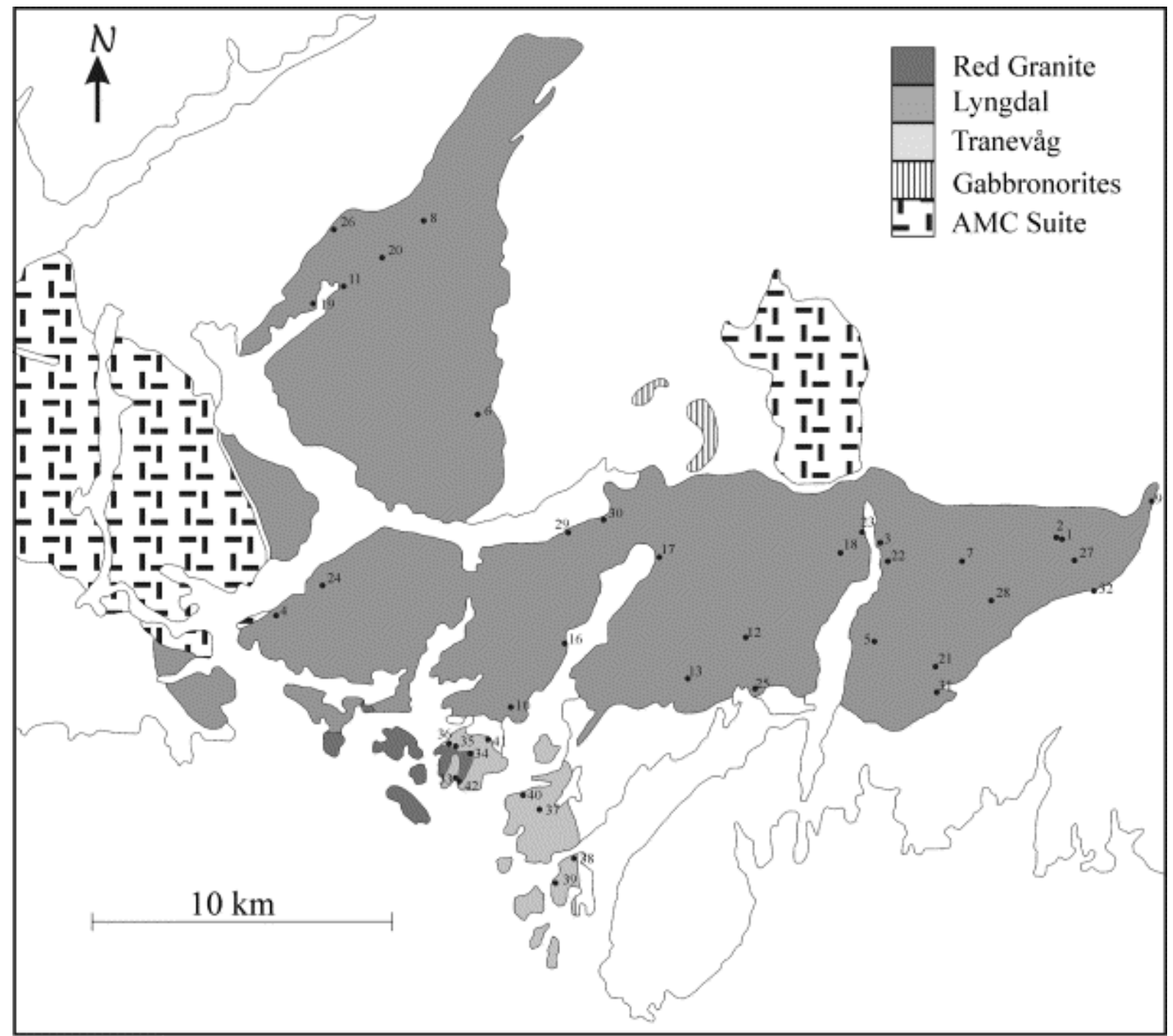

Fig. 2. Sketch map of the Lyngdal complex (Lyngdal granodiorite, Tranevåg and the Red Granite) simplified from Falkum (1982). Dots are the location of the analysed (major and trace elements) samples

The very homogeneous Lyngdal granodiorite contains two kinds of enclaves: (1) angular gneissic enclaves (a few decimetres to several tens of metres in size) locally very abundant near the contacts and (2) oblate mafic microgranular enclaves with an average size of ca. $20 \mathrm{~cm}$. The Tranevåg massif is very similar to the Lyngdal granodiorite but the more differentiated rocks are granitic in composition (see the following). The eastern border of the Tranevåg massif is very rich in crustal xenoliths aligned along both the foliation of the pluton and of the gneissic country-rocks. A porphyritic granite, called the Red Granite due to its coloured alkali feldspar, outcrops near the Tranevåg massif (Fig. 2). Falkum et al. (1979) suggested that the Red Granite post-dates the Tranevåg massif but their mutual relationships are actually difficult to establish. A large zone of enclaves occurs in the Tranevåg massif, near the contact with the Red Granite (\#33 on Fig. 2). Most enclaves are gneissic but some are also oblate mafic microgranular enclaves of metre size. Some of these mafic enclaves contain plagioclase phenocrysts from the host granite, demonstrating a magma mingling process. Pegmatites are widespread in the three plutons and variable in size (from a centimetre large to few decametres). They are abundant near the contacts of the intrusions. Two small undeformed intrusions gabbronorites (called hyperites by Falkum (1982)) outcrop near the 
Lyngdal granodiorite ( $\underline{\text { Fig. 2) }}$. These intrusions were dated at $910 \pm 82 \mathrm{Ma}(\mathrm{Rb}-\mathrm{Sr}$ isochron: Demaiffe et al., 1990).

\subsection{Petrography and mineral chemistry}

\subsubsection{Lyngdal and Tranevåg massifs}

Most of the rocks are porphyritic with plagioclase and alkali feldspar phenocrysts up to $2 \mathrm{~cm}$. The least differentiated facies contain only plagioclase phenocrysts. The matrix consists of the same minerals plus quartz and aggregates of mafic minerals (amphibole, biotite, opaques, apatite, zircon, titanite, \pm allanite). In some samples, amphibole can contain core of clinopyroxene (samples 98N50, 98N29, MB9932: $\mathrm{En}_{33} \mathrm{Fs}_{20} \mathrm{Wo}_{47}$ ).

Plagioclase is a weakly zoned andesine to oligoclase (Table 1) and there is no difference in composition between phenocrysts and matrix plagioclase. They contain inclusions of opaque minerals and commonly form myrmekites at the contact with alkali feldspar. Alkali feldspar varies from perthitic orthoclase to perthitic microcline and often contains inclusions of quartz and plagioclase. Amphibole is a hornblende (magnesio-hastingitic, edenitic, ferro-edenitic hornblendes: Leake, 1978) and is anhedral to euhedral ( $\underline{\text { Table } 2})$. The $X_{\mathrm{Fe}}[\mathrm{Fe} /(\mathrm{Fe}+\mathrm{Mg})$ cationic ratio] varies between 0.44 and 0.58 and displays a positive correlation with the silica content in the whole rock. Biotite is subhedral to euhedral and its proportion increases with the silica content of the rock; in the granites, biotite is more abundant than amphibole. The $X_{\mathrm{Fe}}$ ratio in Lyngdal biotite varies between 0.47 and 0.51 whereas that of Tranevåg has a $X_{\mathrm{Fe}}$ increasing with $\mathrm{SiO}_{2}$ from 0.36 to 0.49 (Table 3). These $X_{\mathrm{Fe}}$ are much lower than in the reduced rapakivi granites (e.g. Sherman, Umiak, Wiborg) but are similar to the more oxidised Proterozoic granitoids (e.g. Jamon). Magnetite is the dominant oxide, with minor ilmenite. Both have been re-equilibrated below the solidus and are often surrounded by a corona of titanite.

\begin{tabular}{|c|c|c|c|c|c|c|c|c|c|c|c|c|}
\hline & \multicolumn{4}{|l|}{ Lyngdal } & \multicolumn{6}{|c|}{ Tranevåg } & \multirow{3}{*}{\multicolumn{2}{|c|}{$\frac{\text { Enclave }}{\text { VDA9912 }}$}} \\
\hline & \multicolumn{2}{|l|}{$98 \mathrm{~N} 34$} & \multicolumn{2}{|l|}{$98 \mathrm{~N} 50$} & \multirow{2}{*}{\multicolumn{2}{|c|}{ VDA9925 }} & \multicolumn{2}{|c|}{ VDA9926 } & \multicolumn{2}{|c|}{ VDA9927 } & & \\
\hline & Core & Rim & Core & Rim & & & Core & Rim & Core & Rim & & \\
\hline $\mathrm{SiO}_{2}$ & 61.05 & 61.31 & 61.90 & 62.25 & 61.62 & 61.61 & 61.48 & 62.17 & 62.82 & 62.93 & 62.27 & 62.13 \\
\hline $\mathrm{Al}_{2} \mathrm{O}_{3}$ & 24.92 & 24.56 & 24.35 & 24.02 & 23.97 & 23.92 & 23.93 & 23.73 & 23.15 & 23.23 & 23.56 & 23.58 \\
\hline $\mathrm{FeO}$ & 0.10 & 0.07 & 0.09 & 0.00 & 0.05 & 0.06 & 0.14 & 0.02 & 0.08 & 0.00 & 0.13 & 0.13 \\
\hline $\mathrm{CaO}$ & 6.68 & 6.14 & 6.04 & 5.76 & 5.59 & 5.48 & 5.73 & 5.21 & 4.66 & 4.71 & 5.22 & 5.23 \\
\hline $\mathrm{Na}_{2} \mathrm{O}$ & 7.68 & 8.11 & 8.05 & 8.39 & 8.43 & 8.46 & 8.34 & 8.48 & 8.94 & 8.87 & 8.65 & 8.68 \\
\hline $\mathrm{K}_{2} \mathrm{O}$ & 0.31 & 0.29 & 0.35 & 0.25 & 0.34 & 0.38 & 0.36 & 0.38 & 0.25 & 0.24 & 0.17 & 0.21 \\
\hline Total & 100.74 & 100.48 & 100.78 & 100.72 & 99.99 & 99.99 & 100.00 & 99.99 & 99.99 & 99.98 & 99.99 & 99.98 \\
\hline \multicolumn{13}{|c|}{ Structural formulae $(80)$} \\
\hline $\mathrm{Si}$ & 2.698 & 2.714 & 2.730 & 2.744 & 2.738 & 2.738 & 2.734 & 2.758 & 2.783 & 2.785 & 2.762 & 2.758 \\
\hline $\mathrm{Al}$ & 1.298 & 1.281 & 1.265 & 1.248 & 1.255 & 1.253 & 1.255 & 1.240 & 1.209 & 1.211 & 1.231 & 1.233 \\
\hline $\mathrm{Fe}$ & 0.004 & 0.003 & 0.003 & 0.000 & 0.002 & 0.002 & 0.005 & 0.001 & 0.003 & 0.000 & 0.005 & 0.005 \\
\hline $\mathrm{Ca}$ & 0.316 & 0.291 & 0.285 & 0.272 & 0.266 & 0.261 & 0.273 & 0.248 & 0.221 & 0.223 & 0.248 & 0.249 \\
\hline $\mathrm{Na}$ & 0.658 & 0.696 & 0.688 & 0.717 & 0.727 & 0.729 & 0.720 & 0.729 & 0.768 & 0.761 & 0.744 & 0.747 \\
\hline $\mathrm{K}$ & 0.017 & 0.016 & 0.019 & 0.014 & 0.019 & 0.021 & 0.021 & 0.022 & 0.014 & 0.014 & 0.010 & 0.012 \\
\hline An & 31.89 & 29.03 & 28.73 & 27.12 & 26.28 & 25.81 & 26.95 & 24.80 & 22.06 & 22.38 & 24.76 & 24.68 \\
\hline $\mathrm{Ab}$ & 66.37 & 69.34 & 69.31 & 71.47 & 71.79 & 72.09 & 71.01 & 73.02 & 76.55 & 76.26 & 74.27 & 74.13 \\
\hline Or & 1.75 & 1.63 & 1.96 & 1.41 & 1.92 & 2.10 & 2.04 & 2.18 & 1.39 & 1.37 & 0.97 & 1.19 \\
\hline
\end{tabular}

Table 1. Plagioclase electron microprobe analyses 


\begin{tabular}{|c|c|c|c|c|c|c|c|c|c|c|c|c|c|}
\hline \multirow[b]{3}{*}{$\mathrm{SiO}_{2}$} & \multicolumn{5}{|l|}{ Lyngdal } & \multicolumn{6}{|l|}{ Tranevåg } & \multirow{2}{*}{\multicolumn{2}{|c|}{$\frac{\text { Enclave }}{\text { VDA9912 }}$}} \\
\hline & \multicolumn{2}{|l|}{$98 \mathrm{~N} 50$} & \multirow{2}{*}{$\begin{array}{l}98 \mathrm{~N} 06 \\
42.50\end{array}$} & \multirow{2}{*}{$\begin{array}{r}98 \mathrm{~N} 29 \\
44.21\end{array}$} & \multirow{2}{*}{$\begin{array}{r}98 \mathrm{~N} 34 \\
42.16\end{array}$} & \multicolumn{2}{|c|}{ VDA9925 } & \multicolumn{2}{|c|}{ VDA9926 } & \multicolumn{2}{|c|}{ VDA9927 } & & \\
\hline & 43.12 & 43.95 & & & & 44.16 & 44.15 & 43.90 & 44.03 & 42.78 & 42.65 & 44.39 & 44.51 \\
\hline $\mathrm{TiO}_{2}$ & 1.84 & 1.92 & 1.59 & 1.90 & 1.99 & 1.70 & 1.63 & 1.39 & 1.52 & 1.40 & 1.57 & 1.19 & 1.27 \\
\hline $\mathrm{Al}_{2} \mathrm{O}_{3}$ & 10.05 & 9.16 & 9.56 & 9.63 & 10.81 & 9.24 & 9.03 & 9.14 & 8.74 & 9.19 & 9.23 & 8.74 & 8.97 \\
\hline $\mathrm{FeO}$ & 17.53 & 17.63 & 19.49 & 17.89 & 21.01 & 15.99 & 16.18 & 17.07 & 17.07 & 19.90 & 20.91 & 16.67 & 16.45 \\
\hline $\mathrm{MnO}$ & 0.49 & 0.50 & 0.45 & 0.13 & 0.46 & 0.66 & 0.57 & 0.70 & 0.70 & 0.56 & 0.54 & 0.30 & 0.34 \\
\hline $\mathrm{MgO}$ & 10.57 & 10.12 & 8.73 & 10.61 & 8.37 & 11.44 & 11.29 & 10.60 & 10.77 & 8.59 & 8.41 & 11.12 & 11.31 \\
\hline $\mathrm{CaO}$ & 11.34 & 11.89 & 11.81 & 11.14 & 10.87 & 11.93 & 11.87 & 11.76 & 11.66 & 11.60 & 11.63 & 12.14 & 12.14 \\
\hline $\mathrm{Na}_{2} \mathrm{O}$ & 1.69 & 1.76 & 1.81 & 1.77 & 1.84 & 1.63 & 1.65 & 1.92 & 1.91 & 1.93 & 1.95 & 1.79 & 1.66 \\
\hline $\mathrm{K}_{2} \mathrm{O}$ & 1.39 & 1.46 & 1.61 & 1.23 & 1.56 & 1.45 & 1.47 & 1.52 & 1.52 & 1.61 & 1.59 & 1.54 & 1.55 \\
\hline $\mathrm{F}$ & 0.94 & 0.71 & 1.08 & 0.79 & 1.06 & 0.70 & 0.72 & 1.37 & 1.37 & 1.33 & 1.34 & 1.39 & 1.38 \\
\hline \multirow[t]{2}{*}{$\mathrm{Cl}$} & 0.16 & 0.13 & 0.19 & 0.14 & 0.33 & 0.24 & 0.23 & 0.17 & 0.16 & 0.19 & 0.19 & 0.05 & 0.05 \\
\hline & 99.12 & 99.23 & 98.82 & 99.44 & 100.46 & 99.14 & 98.78 & 99.54 & 99.45 & 99.08 & 100.00 & 99.32 & 99.62 \\
\hline $\mathrm{O}=\mathrm{F}, \mathrm{Cl}$ & 0.43 & 0.33 & 0.50 & 0.36 & 0.52 & 0.35 & 0.35 & 0.62 & 0.62 & 0.60 & 0.61 & 0.60 & 0.59 \\
\hline Total & 98.69 & 98.90 & 98.32 & 99.08 & 99.94 & 98.79 & 98.43 & 98.92 & 98.83 & 98.47 & 99.39 & 98.73 & 99.03 \\
\hline $\mathrm{H}_{2} \mathrm{O}^{\mathrm{a}}$ & 1.50 & 1.62 & 1.39 & 1.59 & 1.39 & 1.61 & 1.59 & 1.29 & 1.29 & 1.26 & 1.27 & 1.32 & 1.33 \\
\hline Total & 100.19 & 100.52 & 99.71 & 100.67 & 101.32 & 100.40 & 100.02 & 100.21 & 100.12 & 99.74 & 100.66 & 100.04 & 100.36 \\
\hline \multicolumn{14}{|c|}{ Structural formulae (23 $\mathrm{O})$} \\
\hline $\mathrm{Si}$ & 6.513 & 6.624 & 6.541 & 6.619 & 6.410 & 6.618 & 6.646 & 6.636 & 6.661 & 6.597 & 6.548 & 6.694 & 6.679 \\
\hline $\mathrm{Ti}$ & 0.209 & 0.218 & 0.184 & 0.214 & 0.228 & 0.192 & 0.184 & 0.158 & 0.173 & 0.162 & 0.181 & 0.135 & 0.143 \\
\hline $\mathrm{Al}$ & 1.789 & 1.626 & 1.735 & 1.699 & 1.937 & 1.632 & 1.602 & 1.628 & 1.558 & 1.671 & 1.670 & 1.553 & 1.586 \\
\hline $\mathrm{Fe}$ & 2.214 & 2.222 & 2.509 & 2.240 & 2.671 & 2.003 & 2.037 & 2.158 & 2.159 & 2.566 & 2.685 & 2.103 & 2.065 \\
\hline Mn & 0.063 & 0.064 & 0.059 & 0.016 & 0.059 & 0.083 & 0.072 & 0.090 & 0.090 & 0.073 & 0.070 & 0.038 & 0.043 \\
\hline $\mathrm{Mg}$ & 2.380 & 2.273 & 2.003 & 2.368 & 1.897 & 2.555 & 2.534 & 2.389 & 2.429 & 1.975 & 1.925 & 2.500 & 2.530 \\
\hline $\mathrm{Ca}$ & 1.835 & 1.920 & 1.948 & 1.787 & 1.771 & 1.916 & 1.915 & 1.904 & 1.890 & 1.916 & 1.913 & 1.962 & 1.951 \\
\hline $\mathrm{Na}$ & 0.495 & 0.514 & 0.539 & 0.514 & 0.542 & 0.474 & 0.482 & 0.563 & 0.560 & 0.576 & 0.580 & 0.525 & 0.484 \\
\hline $\mathrm{K}$ & 0.268 & 0.281 & 0.317 & 0.235 & 0.303 & 0.278 & 0.281 & 0.293 & 0.293 & 0.317 & 0.310 & 0.295 & 0.297 \\
\hline$F$ & 0.449 & 0.338 & 0.526 & 0.374 & 0.510 & 0.332 & 0.341 & 0.655 & 0.657 & 0.650 & 0.651 & 0.662 & 0.653 \\
\hline $\mathrm{Cl}$ & 0.041 & 0.032 & 0.050 & 0.036 & 0.085 & 0.062 & 0.059 & 0.044 & 0.042 & 0.049 & 0.049 & 0.014 & 0.014 \\
\hline$A 1^{\mathrm{iv}}$ & 1.487 & 1.376 & 1.459 & 1.381 & 1.590 & 1.382 & 1.354 & 1.364 & 1.339 & 1.403 & 1.452 & 1.306 & 1.321 \\
\hline $\mathrm{Al}^{\mathrm{vi}}$ & 0.302 & 0.250 & 0.276 & 0.318 & 0.347 & 0.250 & 0.247 & 0.265 & 0.219 & 0.267 & 0.218 & 0.248 & 0.264 \\
\hline $\mathrm{P}^{\mathrm{b}}$ & 4.1 & 3.4 & 3.9 & 3.7 & 4.7 & 3.4 & 3.3 & 3.4 & 3.1 & 3.6 & 3.6 & 3.1 & 3.2 \\
\hline$X_{\mathrm{Fe}}$ & 0.48 & 0.49 & 0.56 & 0.49 & 0.58 & 0.44 & 0.45 & 0.47 & 0.47 & 0.57 & 0.58 & 0.46 & 0.45 \\
\hline
\end{tabular}

$X \mathrm{Fe}$ is the cationic ratio $\mathrm{Fe} /(\mathrm{Fe}+\mathrm{Mg})$.

a Water calculated to fill up the $(\mathrm{OH}, \mathrm{F}, \mathrm{Cl})$ group.

b Pressure (in kilobars) given by the Al-in-hornblende geobarometer of Johnson and Rutherford (1989).

Table 2. Amphibole electron microprobe analyses 


\begin{tabular}{|c|c|c|c|c|c|c|c|c|}
\hline & \multicolumn{3}{|l|}{ Lyngdal } & \multicolumn{3}{|l|}{ Tranevåg } & \multirow{2}{*}{$\frac{\text { Red Granite }}{\text { VDA9911 }}$} & \multirow{2}{*}{$\begin{array}{l}\text { Enclave } \\
\text { VDA9912 }\end{array}$} \\
\hline & $98 \mathrm{~N} 18$ & $98 \mathrm{~N} 34$ & 98N06 & VDA9925 & VDA9926 & VDA9927 & & \\
\hline $\mathrm{SiO}_{2}$ & 36.62 & 36.79 & 37.70 & 38.59 & 38.30 & 37.39 & 39.71 & 38.15 \\
\hline $\mathrm{TiO}_{2}$ & 3.71 & 4.3 & 3.13 & 3.29 & 3.68 & 2.91 & 1.77 & 3.32 \\
\hline $\mathrm{Al}_{2} \mathrm{O}_{3}$ & 14 & 13.51 & 12.94 & 13.22 & 12.63 & 12.22 & 11.95 & 12.58 \\
\hline $\mathrm{FeO}$ & 21.17 & 20.88 & 19.17 & 15.20 & 16.73 & 20.05 & 13.73 & 16.08 \\
\hline $\mathrm{MnO}$ & 0.21 & 0.17 & 0.33 & 0.31 & 0.30 & 0.25 & 0.68 & 0.11 \\
\hline $\mathrm{MgO}$ & 11.33 & 11.23 & 12.26 & 15.11 & 14.02 & 11.86 & 15.98 & 14.43 \\
\hline $\mathrm{CaO}$ & 0.1 & 0 & 0.02 & 0.02 & 0.02 & 0.04 & 0.00 & 0.02 \\
\hline $\mathrm{Na}_{2} \mathrm{O}$ & 0.07 & 0.09 & 0.08 & 0.07 & 0.09 & 0.06 & 0.13 & 0.07 \\
\hline $\mathrm{K}_{2} \mathrm{O}$ & 9.25 & 9.58 & 10.28 & 10.51 & 10.41 & 10.17 & 10.60 & 10.31 \\
\hline $\mathrm{F}$ & 1.63 & 1.92 & 2.19 & 1.61 & 2.69 & 1.95 & 5.16 & 2.94 \\
\hline \multirow[t]{2}{*}{$\mathrm{Cl}$} & 0.21 & 0.26 & 0.19 & 0.31 & 0.19 & 0.19 & 0.29 & 0.05 \\
\hline & 98.3 & 98.73 & 98.29 & 98.24 & 99.07 & 97.08 & 100.00 & 98.08 \\
\hline $\mathrm{O}=\mathrm{F}, \mathrm{Cl}$ & 0.73 & 0.87 & 0.97 & 0.75 & 1.18 & 0.87 & 2.24 & 1.25 \\
\hline Total & 97.57 & 97.86 & 97.32 & 97.49 & 97.89 & 96.22 & 97.76 & 96.83 \\
\hline $\mathrm{H}_{2} \mathrm{O}^{\mathrm{a}}$ & 3.11 & 2.96 & 2.84 & 3.19 & 2.66 & 2.90 & 1.46 & 2.55 \\
\hline Total & 100.68 & 100.82 & 100.17 & 100.68 & 100.55 & 99.11 & 99.22 & 99.38 \\
\hline \multicolumn{9}{|c|}{ Structural formulae (22 O) } \\
\hline $\mathrm{Si}$ & 5.579 & 5.602 & 5.750 & 5.744 & 5.758 & 5.793 & 5.985 & 5.778 \\
\hline $\mathrm{Ti}$ & 0.425 & 0.492 & 0.360 & 0.369 & 0.415 & 0.339 & 0.201 & 0.378 \\
\hline Al & 2.514 & 2.425 & 2.327 & 2.319 & 2.237 & 2.232 & 2.122 & 2.246 \\
\hline $\mathrm{Fe}$ & 2.697 & 2.659 & 2.446 & 1.892 & 2.103 & 2.597 & 1.731 & 2.037 \\
\hline $\mathrm{Mn}$ & 0.027 & 0.022 & 0.043 & 0.040 & 0.039 & 0.033 & 0.087 & 0.014 \\
\hline $\mathrm{Mg}$ & 2.573 & 2.549 & 2.786 & 3.352 & 3.142 & 2.738 & 3.589 & 3.256 \\
\hline $\mathrm{Ca}$ & 0.016 & 0.000 & 0.002 & 0.004 & 0.002 & 0.006 & 0.000 & 0.004 \\
\hline $\mathrm{Na}$ & 0.021 & 0.027 & 0.023 & 0.021 & 0.027 & 0.017 & 0.039 & 0.021 \\
\hline $\mathrm{K}$ & 1.798 & 1.861 & 2.000 & 1.996 & 1.996 & 2.010 & 2.039 & 1.992 \\
\hline $\mathrm{F}$ & 0.785 & 0.925 & 1.058 & 0.756 & 1.281 & 0.957 & 2.459 & 1.410 \\
\hline $\mathrm{Cl}$ & 0.054 & 0.067 & 0.050 & 0.077 & 0.049 & 0.049 & 0.075 & 0.014 \\
\hline$X_{\mathrm{Fe}}$ & 0.51 & 0.51 & 0.47 & 0.36 & 0.40 & 0.49 & 0.33 & 0.38 \\
\hline
\end{tabular}

Table 3. Biotite electron microprobe analyses

Fig. 3 illustrates the sequence of crystallisation deduced from petrographical observations. Liquidus minerals are oxides, apatite and clinopyroxene. At lower temperature, as observed experimentally (Bogaerts et al., 2001), clinopyroxene breaks down to amphibole and is only recovered in natural samples as core in amphibole. Plagioclase is the first tectosilicate to crystallise, K-feldspar and quartz being late in the sequence of crystallisation.

\begin{tabular}{|l|l|}
\hline \multicolumn{2}{|l|}{ Mgt, Ilm, Apatite } \\
\hline Cpx & \\
\hline & Plagioclase, Hbl, Zircon \\
\hline & Biotite \\
\hline & Qtz, FK, titanite \\
\hline
\end{tabular}

Fig. 3. Sequence of crystallisation for the Lyngdal granodiorite as deduced from petrographical observations. Mineral abbreviations: Mgt, magnetite; Ilm, ilmenite; Cpx, clinopyroxene; Hbl, hornblende; Qtz, quartz; FK, potassic feldspar. 


\subsubsection{The Red Granite}

This is a porphyritic granite with red K-feldspar (perthitic microcline) and plagioclase as phenocrysts (sericitised); myrmekites are widespread. The matrix is composed of the same minerals with quartz and scarce biotite often chloritised. Biotite in the Red Granite has a lower $X_{\mathrm{Fe}}$ (ca. 0.33$)$ and Ti content than Tranevåg biotite $\left(X_{\mathrm{Fe}} 0.49\right)$ and is very F-rich (above $5.12 \mathrm{wt} . \% \mathrm{~F})$. Accessory minerals include opaques, apatite, zircon, allanite and fluorite. Fluorite is usually interleaved with biotite and seems to replace it.

\subsubsection{Mafic microgranular enclaves}

The enclaves have an equigranular structure (average grain size $0.5 \mathrm{~mm}$ ), with elongated anhedral to euhedral plagioclase, amphibole and biotite. Amphibole and plagioclase are rich in oxides and apatite needles. Quartz is present in small amount. Zircon is only present as small inclusions in biotite. The mineral composition is similar to those of Lyngdal-Tranevåg massifs: plagioclase is weakly zoned $\left(\mathrm{An}_{25}\right), X_{\mathrm{Fe}}$ is around 0.38 in biotite and around 0.46 in amphibole. Some euhedral plagioclases show an irregular overgrowth rim. These microstructures (elongate grain shapes, apatite needles, plagioclase overgrowths) reflect an igneous origin (Vernon, 1991).

\subsection{Estimation of intensive parameters from mineral equilibria}

Many experimental and empirical calibrations have been done to estimate pressure with the Al-in-hornblende geobarometer (Anderson and Smith, 1995 for a review). Studied granitoids contain the appropriate mineral assemblage to use these geobarometers (see Section 3.2). Amphiboles from the Lyngdal granodiorite give a pressure of ca. $4 \mathrm{kbar}$ with the experimental calibration of Johnson and Rutherford (1989) while the calibration of Schmidt (1992) gives pressure higher by $1.3 \mathrm{kbar}$ due to the temperature effect discussed by Anderson and Smith (1995). Amphiboles from the Tranevåg massif give a slightly lower pressure $(P<3.6 \mathrm{kbar})$ than those from the Lyngdal granodiorite. The stability of the assemblage titanite, magnetite and quartz implies that $\mathrm{fO}_{2}$ was at least $\mathrm{NNO}$ (Wones, 1989).

\section{Analytical methods and selected samples}

Analysed samples include the Lyngdal granodiorite, the Tranevåg massif, the Red Granite and two samples of mafic enclaves (VDA9912 and MB2002). The analyses of gabbronorites are from Demaiffe et al. (1990). X-ray fluorescence (CGR Lambda 2020 spectrometer and ARL $94000 \mathrm{XP}$, Université de Liège) was used to analyse major elements and some trace elements $(\mathrm{Rb}, \mathrm{Sr}, \mathrm{Zr}, \mathrm{Zn}, \mathrm{Nb}, \mathrm{Y})$. The sample preparation and analytical procedure is that described by Bologne and Duchesne (1991) for the CGR Lambda 2020 spectrometer. Other trace elements (REE, Y, Co, Cu, V, Cr, Ni, Ga, Hf, Nb, Ta, Pb, Th, U, Ba) were analysed by ICP-MS (VG Elemental Plasma Quad PQ2, Université de Liège) following the method described by Vander Auwera et al. (1998a).

Minerals have been analysed with the Cameca SX50 electron microprobe of the CAMST ('Centre d'Analyse par Microsonde pour les Sciences de la Terre', Louvain-La-Neuve) and the Cameca Camebax electron microprobe of 'Services Communs BRGM-CNRS-UO, Orléans'. Standards included natural minerals and synthetic compounds. For the Cameca SX50, the accelerating voltage was $15 \mathrm{kV}$ and the beam current was $20 \mathrm{nA}$. Counting times 
were $30 \mathrm{~s}$ except for Si (20 s), Mg (40 s), Ba (80 s) and F (60 s). For the Cameca Camebax, the accelerating voltage was $15 \mathrm{kV}$ and the beam current was $12 \mathrm{nA}$. Counting times were $10 \mathrm{~s}$, except for $\mathrm{F}$ and $\mathrm{Cl}(30 \mathrm{~s})$.

The analytical procedure for $\mathrm{Sr}-\mathrm{Nd}$ isotopic compositions is described below. After acid dissolution of the sample and $\mathrm{Sr}$ and $\mathrm{Nd}$ separation on ion-exchange resin, $\mathrm{Sr}$ isotopic compositions have been measured on Ta simple filament and $\mathrm{Nd}$ isotopic compositions on triple T-Re-Ta filament on a Micromass Sector 54. Repeated measurements of Sr and $\mathrm{Nd}$ standards have shown that between-run error is better than 0.000015 . Within-run errors are generally lower. During the days of measurements, the NBS987 standard has given a value for ${ }^{87} \mathrm{Sr} /{ }^{86} \mathrm{Sr}$ of $0.710274 \pm 0.000011$ ( $2 \sigma$ on the mean, four measurements, normalised to $\left.{ }^{86} \mathrm{Sr} /{ }^{88} \mathrm{Sr}=0.1194\right)$ and the Rennes Nd standard a value for ${ }^{143} \mathrm{Nd} /{ }^{144} \mathrm{Nd}$ of $0.511956 \pm 0.000012$ ( $2 \sigma$ on the mean, eight measurements, normalised to ${ }^{146} \mathrm{Nd} /{ }^{144} \mathrm{Nd}=0.7219$ : Chauvel and Blichert-Toft, 2001), corresponding to a La Jolla value of 0.511851. All measured ratios have been recalculated to the recommended values of 0.71025 for NBS987 and 0.511963 for Rennes standard. $\mathrm{Rb}$ and $\mathrm{Sr}$ concentrations have been measured by X-ray fluorescence. The error on the $\mathrm{Rb} / \mathrm{Sr}$ ratio is evaluated to be $4 \%$. Sm and $\mathrm{Nd}$ concentrations were measured by ICP-MS. The Rb-Sr and Sm-Nd ages have been calculated following Ludwig (2001). Used decay constants ( Steiger and Jäger, 1977) are $1.42 \times 10^{-11} \mathrm{a}^{-1}\left({ }^{87} \mathrm{Rb}\right)$ and $6.54 \times 10^{-12} \mathrm{a}^{-1}$ $\left({ }^{147} \mathrm{Sm}\right)$.

\section{Geochemistry}

\subsection{Results for granitoids}

Whole rock analyses (major and trace elements) are listed in Table 4. All the analysed samples from the Lyngdal massif ranges between 59.6 and 65.6 wt.\% $\mathrm{SiO}_{2}$. The Tranevåg samples show a larger trend between 56.3 and $71.7 \mathrm{wt} . \% \mathrm{SiO}_{2}$. The Red Granite ranges between 71.2 and 75.2 wt.\% $\mathrm{SiO}_{2}$. In the cationic classification of Debon and Le Fort (1988; Fig. 4), granitoids plot mostly between the quartz monzodiorite and granite field, through the granodiorite and adamellite (=monzogranite) fields. In TAS diagram (Total Alkali Silica, Fig. $\underline{5 \mathrm{~A}})$, the rocks often straddle between the limits defined by Kuno and Irvine and Baragar (Rickwood, 1989) but only one Tranevåg sample is clearly located in the alkaline field (VDA9924). As the agpaitic index [molecular $\left(\mathrm{Na}_{2} \mathrm{O}+\mathrm{K}_{2} \mathrm{O}\right) / \mathrm{Al}_{2} \mathrm{O}_{3}$, Fig. 5C] of Lyngdal and Tranevåg is $<0.87$ (except sample VDA9924 from the Tranevåg massif), these two intrusions are subalkaline following Liégeois and Black (1987). All the three massifs are indeed metaluminous and the $\mathrm{A} / \mathrm{CNK}$ ratio [molecular $\mathrm{Al}_{2} \mathrm{O}_{3} /\left(\mathrm{CaO}+\mathrm{Na}_{2} \mathrm{O}+\mathrm{K}_{2} \mathrm{O}\right)$ ] increases with the silica content. Fig. 5B show that the samples define a calc-alkaline trend in the Peacock diagram (and HKCA-shoshonitic after Peccerillo and Taylor, 1976; figure not shown) but the $\mathrm{FeO}_{\mathrm{t}} / \mathrm{MgO}$ ratio is too high to be characteristic of the calc-alkaline series. Indeed in the AFM diagram (Fig. 6), the Lyngdal trend is tholeiitic/alkaline. In comparison with HKCA postcollisional intrusions (e.g. Liégeois et al., 1998), the Lyngdal granodiorite is enriched in Ti, P, $\mathrm{Fe}$, HFSE (e.g. Zr, Nb), REE (mainly the HREE), Y, Zn, strongly depleted in Al, Cr, Ni, V and slightly depleted in $\mathrm{Mg}$ and $\mathrm{Ca}$. The $\mathrm{K} / \mathrm{Na}$ ratio is also higher. The enrichment in $\mathrm{Zr}$ and REE gives an A-type character to these granitoids after the geochemical classification of Whalen et al. (1987). When compared to the mildly shoshonitic Tismana pluton ( Duchesne et al., 1998), using the sliding normalisation proposed by Liégeois et al. (1998) where each studied rock is normalised to the interpolated rock from the reference series (the YenchichiTelabit series) that has the same silica content, the Lyngdal plutons appear distinct for HFSE and REE ( Fig. 7). The Tismana pluton is also subalkaline, metaluminous to weakly 
peraluminous and A-type after Whalen et al. (1987) but Duchesne et al. (1998) do not, however, consider this pluton as A-type: it shares some geochemical characteristics with the A-type series as a result of its shoshonitic signature but it is neither anorogenic nor anhydrous and alkaline, like the original definition of A-type granitoids by Loiselle and Wones (1979). King et al. (1997) noted that this original definition is actually not accurate to describe the Atype granitoids of the Lachlan Fold Belt and proposed the term 'aluminous A-type' to distinguish the metaluminous to weakly peraluminous from the peralkaline A-type granitoids. However, when compared to the Iforas alkaline-peralkaline granitoids using the sliding normalisation ( Fig. 7), the Lyngdal plutons appear very similar. This indicates that the Lyngdal massifs have many of the geochemical characteristics of the alkaline-peralkaline series except one fundamental, the $\mathrm{Na}_{2} \mathrm{O}$ content, which expresses itself in the mineralogy: sodic amphibole and pyroxene in the Iforas rocks and calcic amphibole in Lyngdal. The comparison between Lyngdal, Tismana and the Iforas raises the problem to classify these granitoids and to give a name to these series. To underline its high $\mathrm{FeO}_{\mathrm{t}} / \mathrm{MgO}$ ratio and $\mathrm{K}_{2} \mathrm{O}$ content, as well as its high HFSE and REE content, we classify our plutons as ferro-potassic A-type granitoids

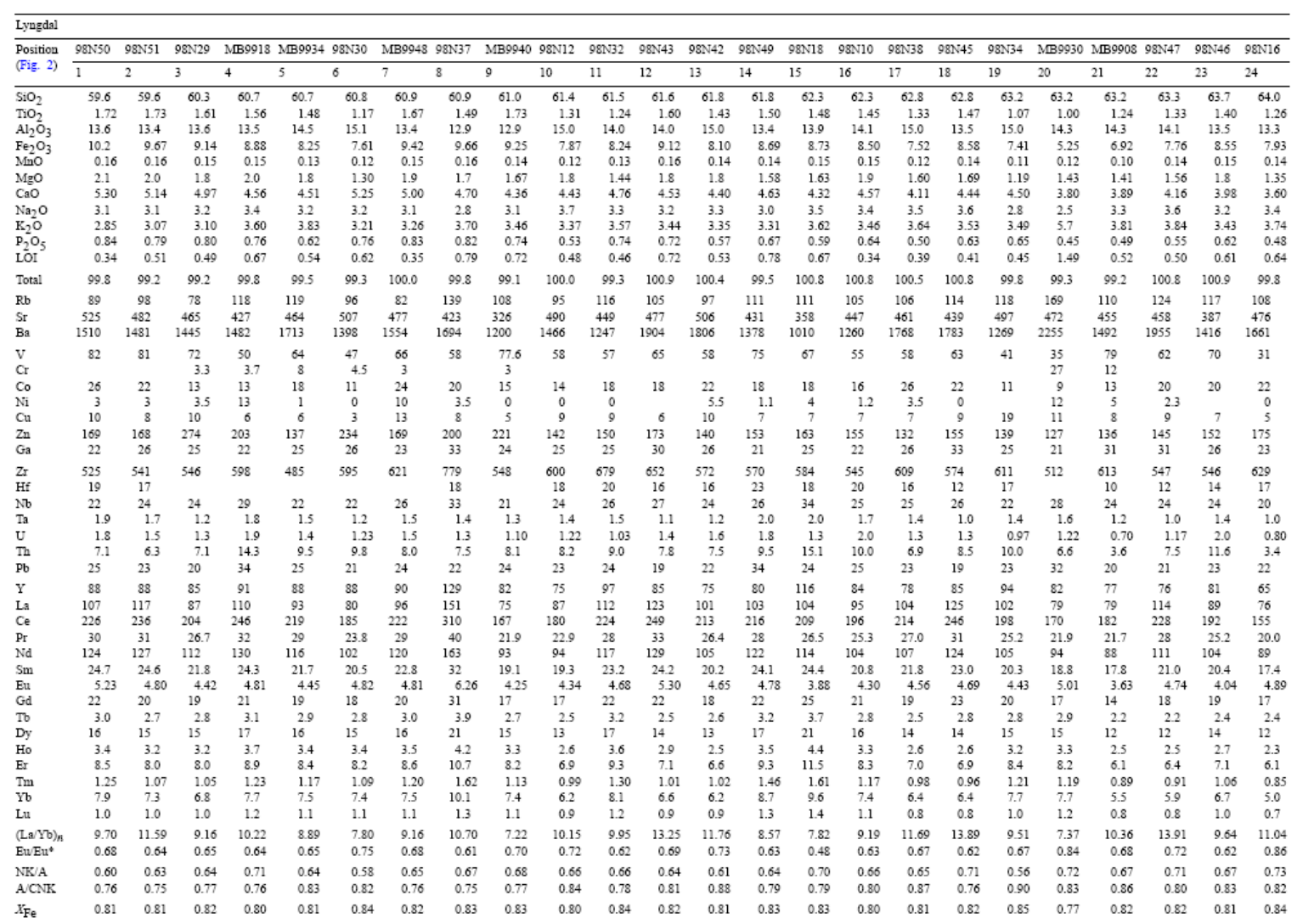




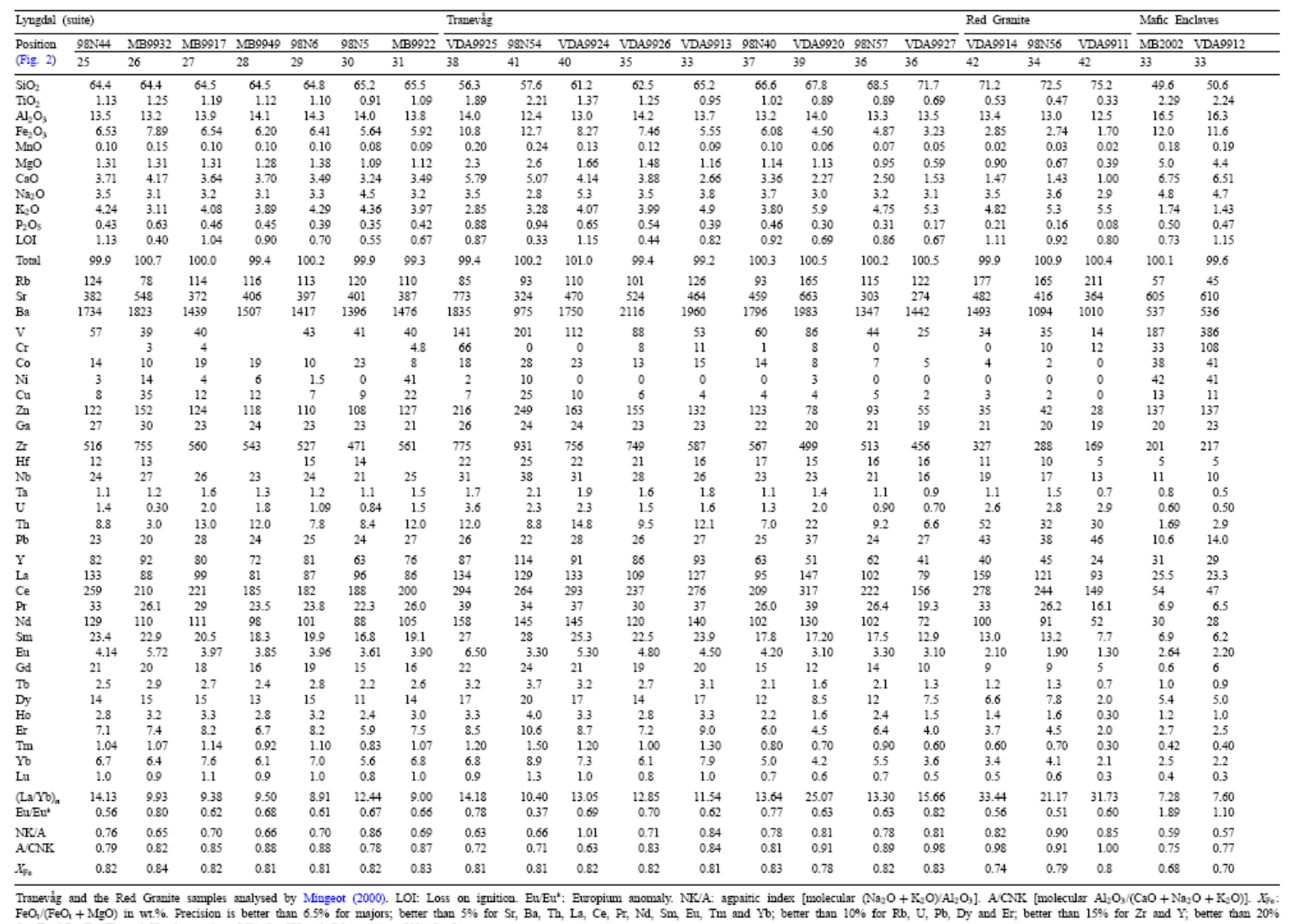

Table 4. Whole rock major-(in wt.\%) and trace element (in ppm) compositions of Lyngdal, Tranevåg, the Red Granite and the mafic enclaves

Tranevåg and the Red Granite samples analysed by Mingeot (2000). LOI: Loss on ignition. Eu/Eu ${ }^{*}:$ Europium anomaly. NK/A: agpaitic index [molecular $\left(\mathrm{Na}_{2} \mathrm{O}+\mathrm{K}_{2} \mathrm{O}\right) / \mathrm{Al}_{2} \mathrm{O}_{3}$ ]. A/CNK [molecular $\mathrm{Al}_{2} \mathrm{O}_{3} /\left(\mathrm{CaO}+\mathrm{Na}_{2} \mathrm{O}+\mathrm{K}_{2} \mathrm{O}\right)$ ]. $X_{\mathrm{Fe}}: \mathrm{FeO}_{\mathrm{t}} /\left(\mathrm{FeO}_{\mathrm{t}}+\mathrm{MgO}\right)$ in wt.\%. Precision is better than $6.5 \%$ for majors; better than $5 \%$ for $\mathrm{Sr}, \mathrm{Ba}, \mathrm{Th}, \mathrm{La}, \mathrm{Ce}$, $\mathrm{Pr}, \mathrm{Nd}, \mathrm{Sm}, \mathrm{Eu}, \mathrm{Tm}$ and $\mathrm{Yb}$; better than $10 \%$ for $\mathrm{Rb}, \mathrm{U}, \mathrm{Pb}$, Dy and Er; better than $15 \%$ for $\mathrm{Zr}$ and $\mathrm{Y}$; better than $20 \%$ for $\mathrm{Zn}, \mathrm{Nb}$, Ta, Tb and $\mathrm{Ho}$; better than $26 \%$ for $\mathrm{Hf}$ and $\mathrm{Gd}$; and is $50 \%$ for $\mathrm{Lu}$.

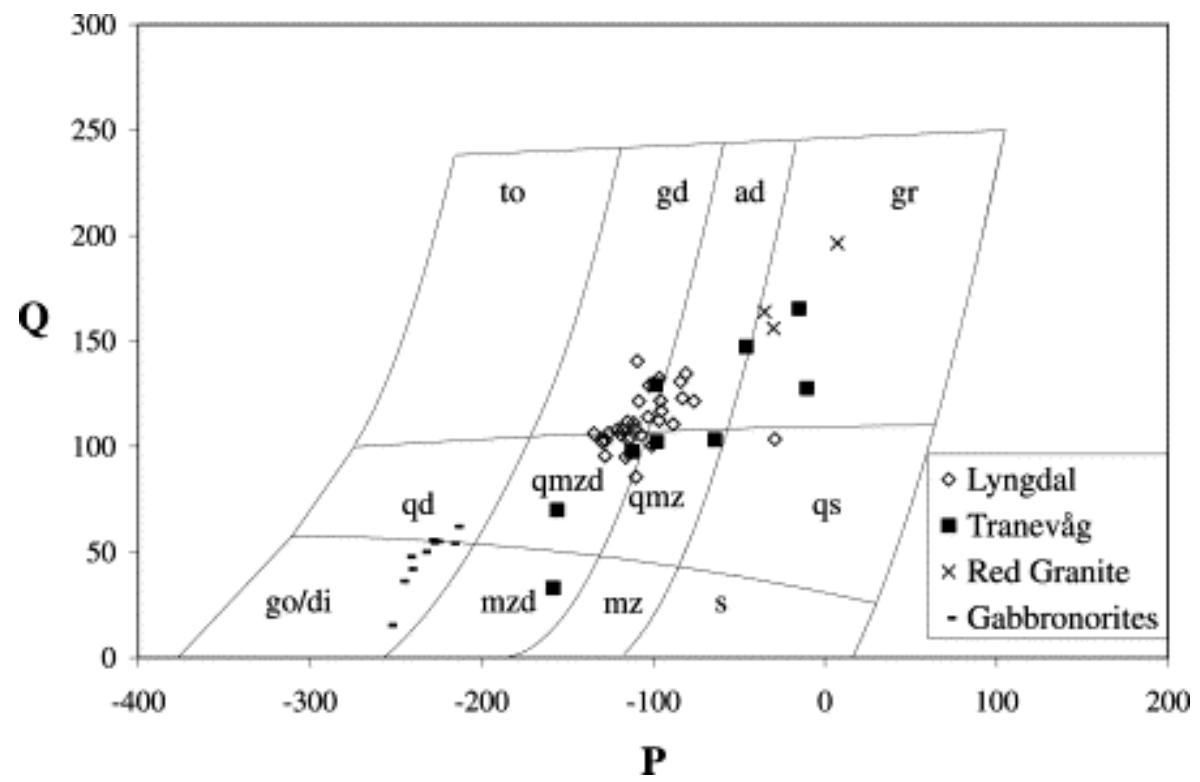

Fig. 4. Cationic classification of Debon and Le Fort (1988). $Q=(\mathrm{Si} / 3)-[\mathrm{K}+\mathrm{Na}+(2 \mathrm{Ca} / 3)]$ against $\mathrm{P}=\mathrm{K}-\mathrm{Na}-\mathrm{Ca}$ diagram. go/di: gabbro or diorite, mzd: monzodiorite, mz: monzonite, s: syenite, qd: quartz diorite, qmzd: quartz monzodiorite, qmz: quartz monzonite, qs: quartz syenite, to: tonalite, gd: granodiorite, ad: adamellite, gr: granite. 


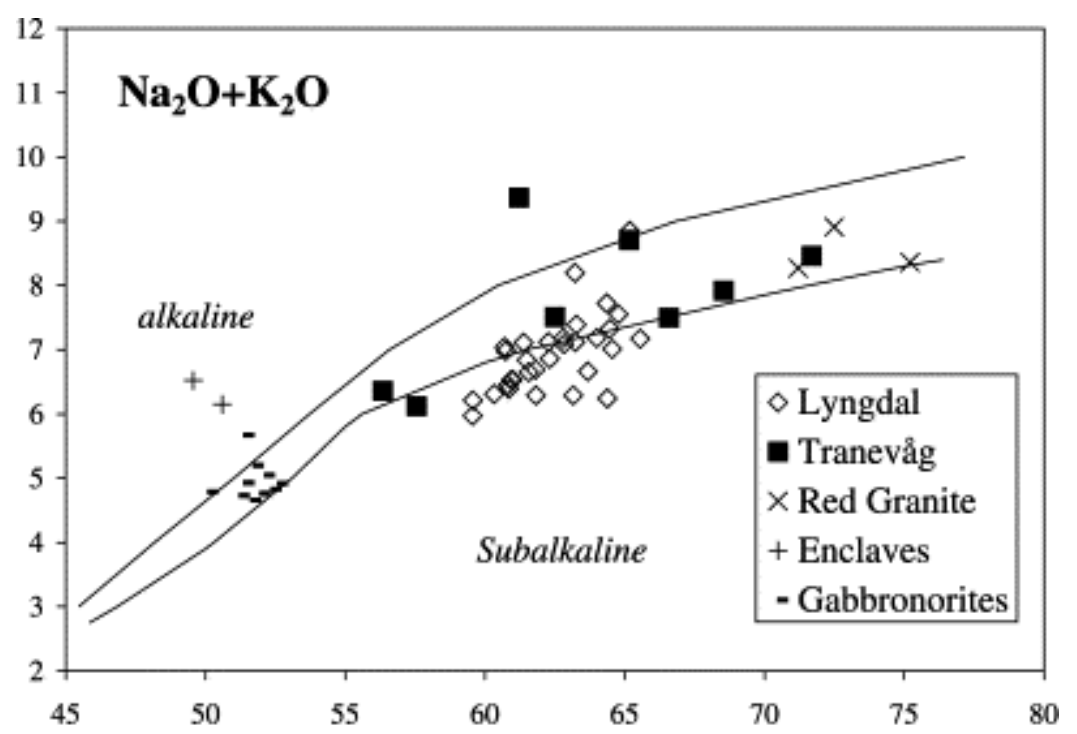

(A)

$\mathrm{SiO}_{2}$

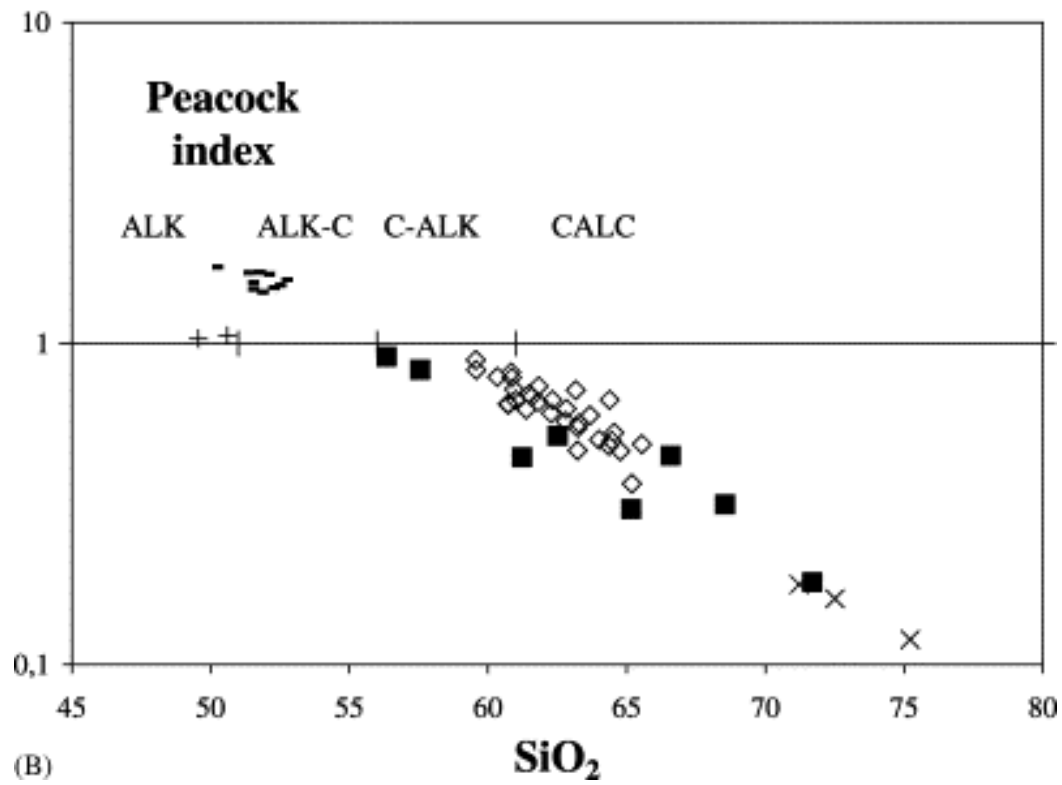



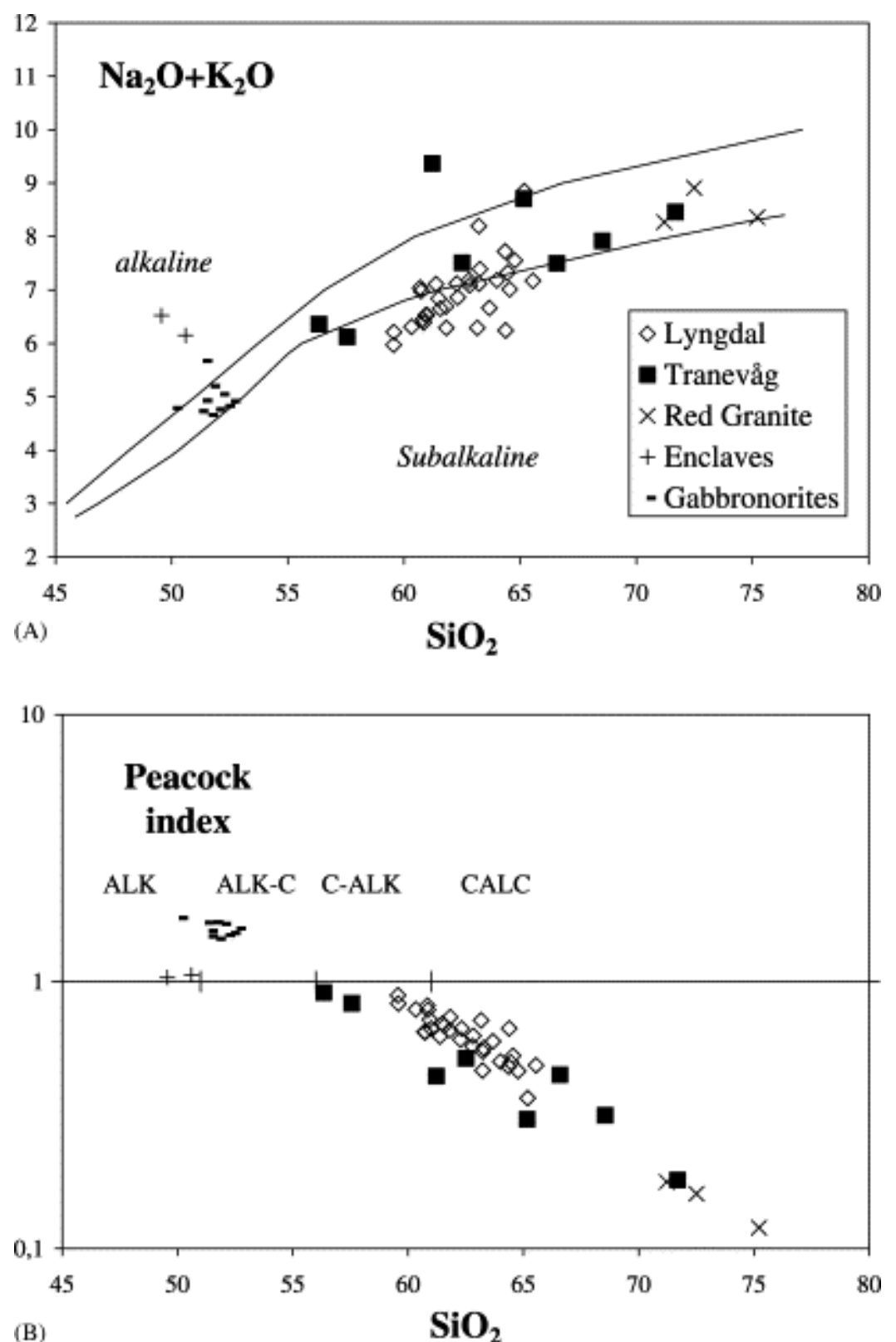

Fig. 5. Classification diagrams. (A) TAS diagram (wt. $\% \mathrm{Na}_{2} \mathrm{O}+\mathrm{K}_{2} \mathrm{O}$ vs. $\mathrm{SiO}_{2}$ ). The two boundaries between the subalkaline and alkaline domain are from Rickwood (1989). (B) Peacock index [wt.\% $\mathrm{CaO} /\left(\mathrm{Na}_{2} \mathrm{O}+\mathrm{K}_{2} \mathrm{O}\right)$ vs. $\mathrm{SiO}_{2}$ ]. ALK: alkaline, ALK-C: alkali-calcic, C-ALK: calc-alkaline, CALC: calcic. (C) Agpaitic index [molar $(\mathrm{Na}+\mathrm{K}) / \mathrm{Al}]$. The limit at $\mathrm{AI}=0.87$ separates subalkaline metaluminous granitoids from alkaline metaluminous granitoids (Liégeois and Black, 1987). 


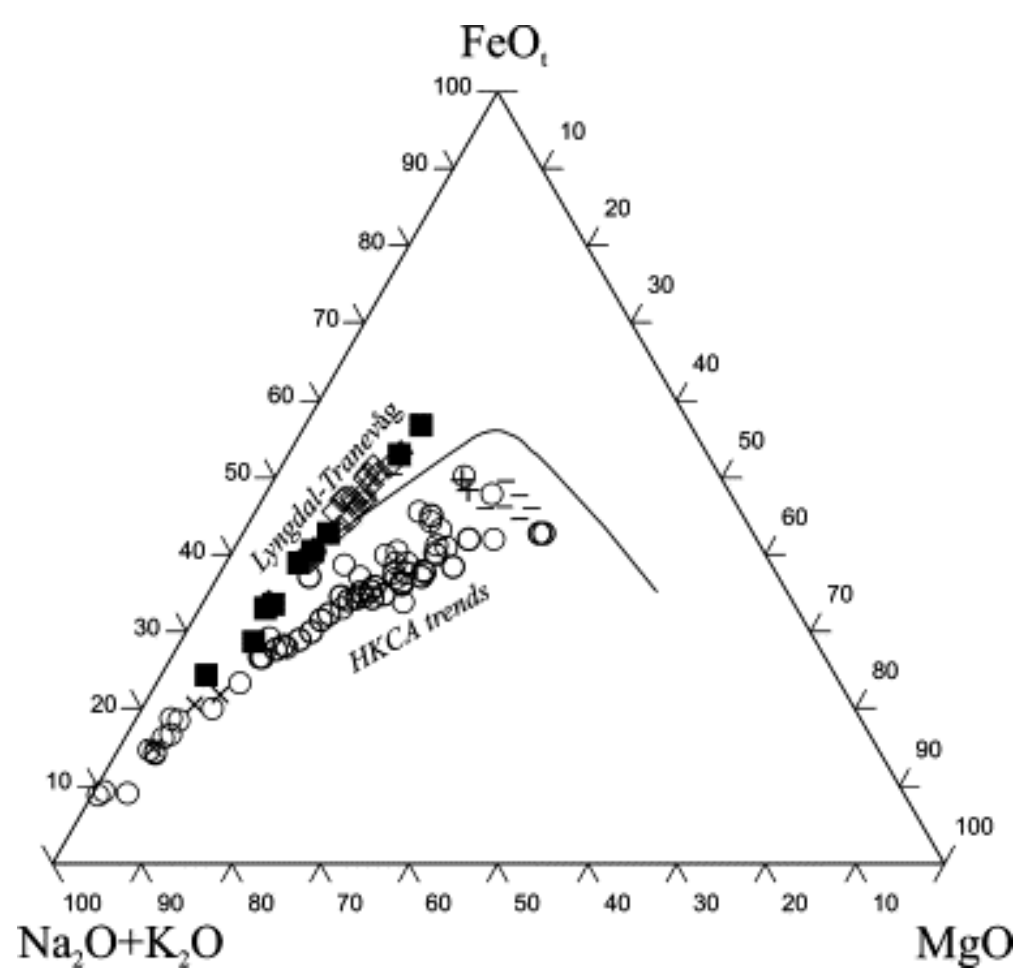

Fig. 6. AFM diagram. $\left(\mathrm{A}=\mathrm{Na}_{2} \mathrm{O}+\mathrm{K}_{2} \mathrm{O}, \mathrm{F}=\mathrm{FeO}, \mathrm{M}=\mathrm{MgO}\right)$. The boundary between the tholeiite and the calcalkaline series is from Rickwood (1989). Same symbols as in Fig. 5 for the studied samples. Open circles are HKCA data from van Marcke de Lummen and Vander Auwera (1990), Feeley and Davidson (1994), Liégeois et al. (1998). 


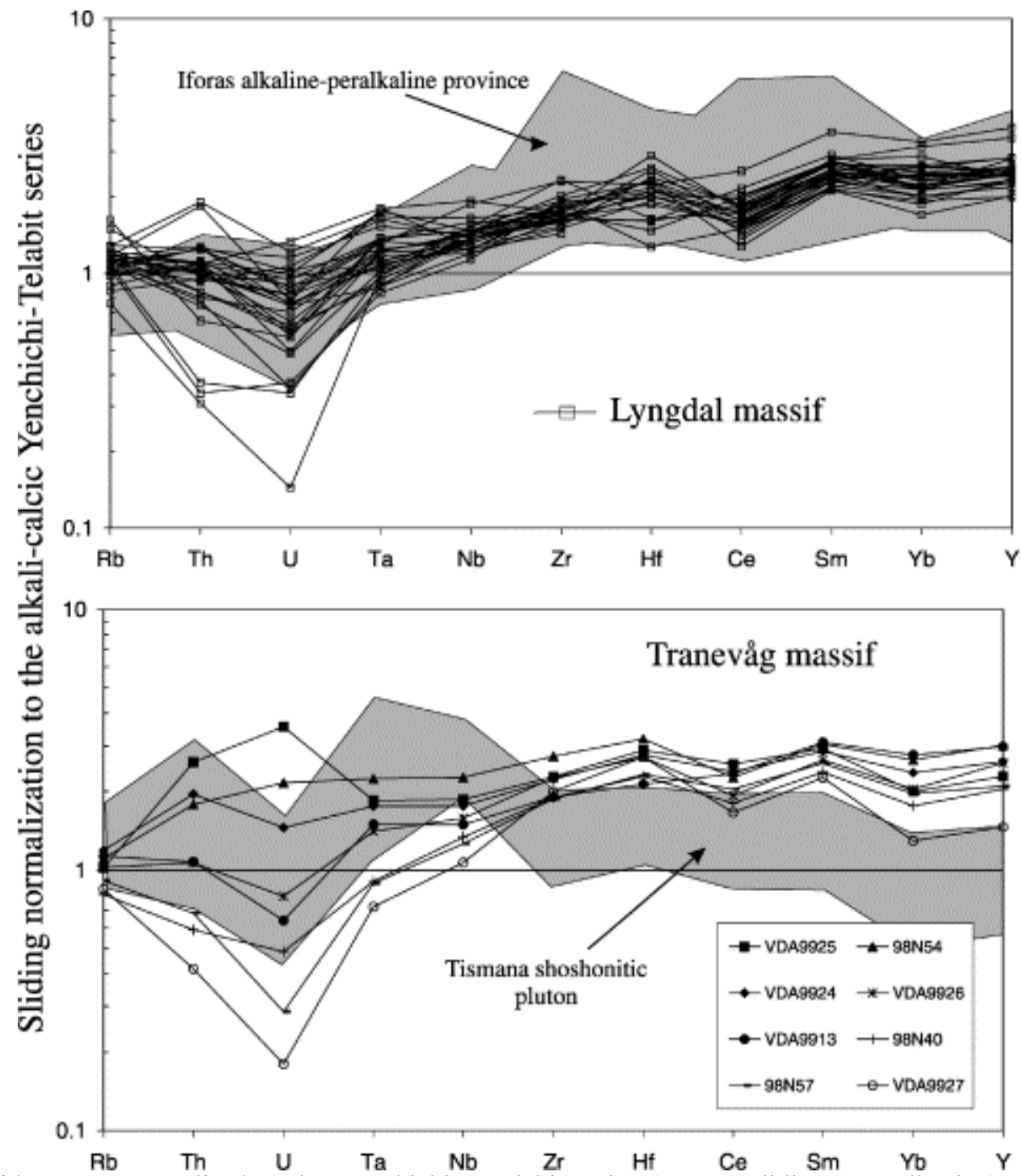

Fig. 7. Spidergrams normalised to the Yenchichi 2-Telabit series (NYTS, sliding normalisation). See text for explications.

Fig. 8 and Fig. 9 show Harker diagrams for selected major and trace elements. The major elements define a similar trend for the three massifs. All elements clearly decrease as silica increases except for $\mathrm{K}_{2} \mathrm{O}$ which increases and $\mathrm{Al}_{2} \mathrm{O}_{3}$ which is relatively constant. The $X_{\mathrm{Fe}}$ $\left[\mathrm{FeO}_{\mathrm{t}} /\left(\mathrm{FeO}_{\mathrm{t}}+\mathrm{MgO}\right)\right]$ increases continuously with $\mathrm{SiO}_{2}$ in the Tranevåg massif (from 0.81 to 0.83 ), except one sample (VDA9920) with $X_{\mathrm{Fe}}=0.78 . X_{\mathrm{Fe}}$ from the Lyngdal granodiorite overlap with those of the Tranevåg massif except for some samples (in the west of the intrusion and at its eastern border) which have a slightly higher $X_{\mathrm{Fe}}$ ratio. The Red Granite has a lower $X_{\mathrm{Fe}}$ than the two other massifs (between 0.74 and 0.80 ). MORB-normalised diagram (Fig. 10) shows that trace elements are identical in the Lyngdal and Tranevåg massifs. They display the same enrichment in LILE and negative anomalies in Ti-Nb-Ta and P. Some trace elements (Fig. 9 and Fig. 10) distinguish the Lyngdal and Tranevåg massifs from the Red Granite, in particular Sr and Th that are significantly more abundant in the Red Granite. The REE (Fig. 11) also discriminate them: the $(\mathrm{La} / \mathrm{Yb})_{n}$ ratio is always $<16$ for Lyngdal-Tranevåg and always $>21$ for the Red Granite. The $(\mathrm{Gd} / \mathrm{Lu})_{n}$ ratio is low, between 1.78 and 2.94 and is similar in the three massifs. This rather flat MREE-HREE pattern indicates that garnet is neither a fractionating mineral nor a residual phase in the source of the granitoids. Sample VDA9920 (Tranevåg massif) has the same geochemical characteristics than the Red Granite and thus is out of the Lyngdal-Tranevåg trend for LREE, Th and Sr. 

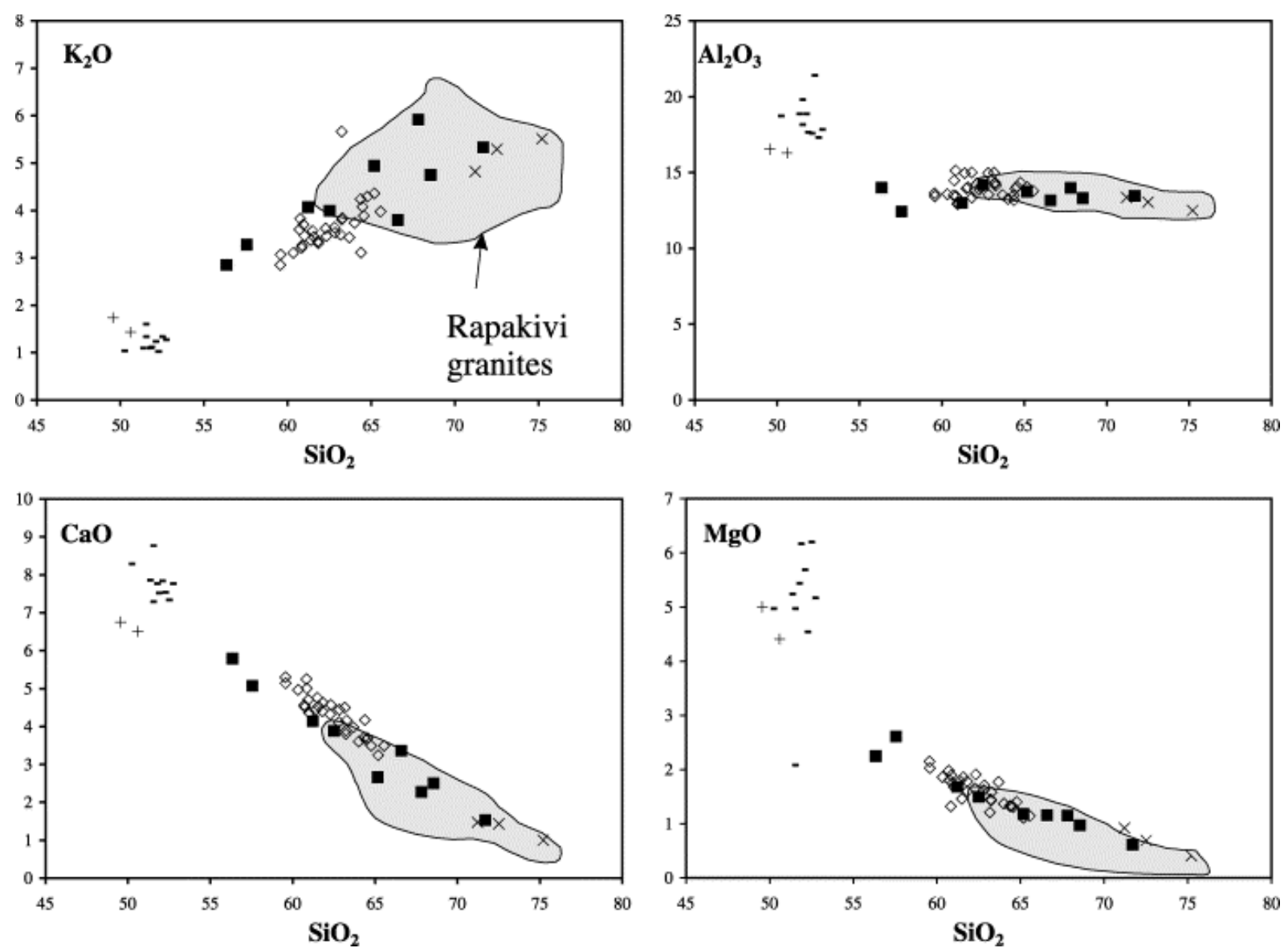

Fig. 8. Major element content (wt.\%) vs. wt.\% $\mathrm{SiO}_{2}$. Rapakivi granites are shown as shaded fields (Jamon: Dall'Agnol et al. (1999c); Sherman granite: Frost et al. (1999); Finnish rapakivi granites: Rämö and Haapala (1995); NPS: Emslie and Stirling (1993); Proterozoic A-type granites of Southwest USA: Anderson and Bender (1989)).
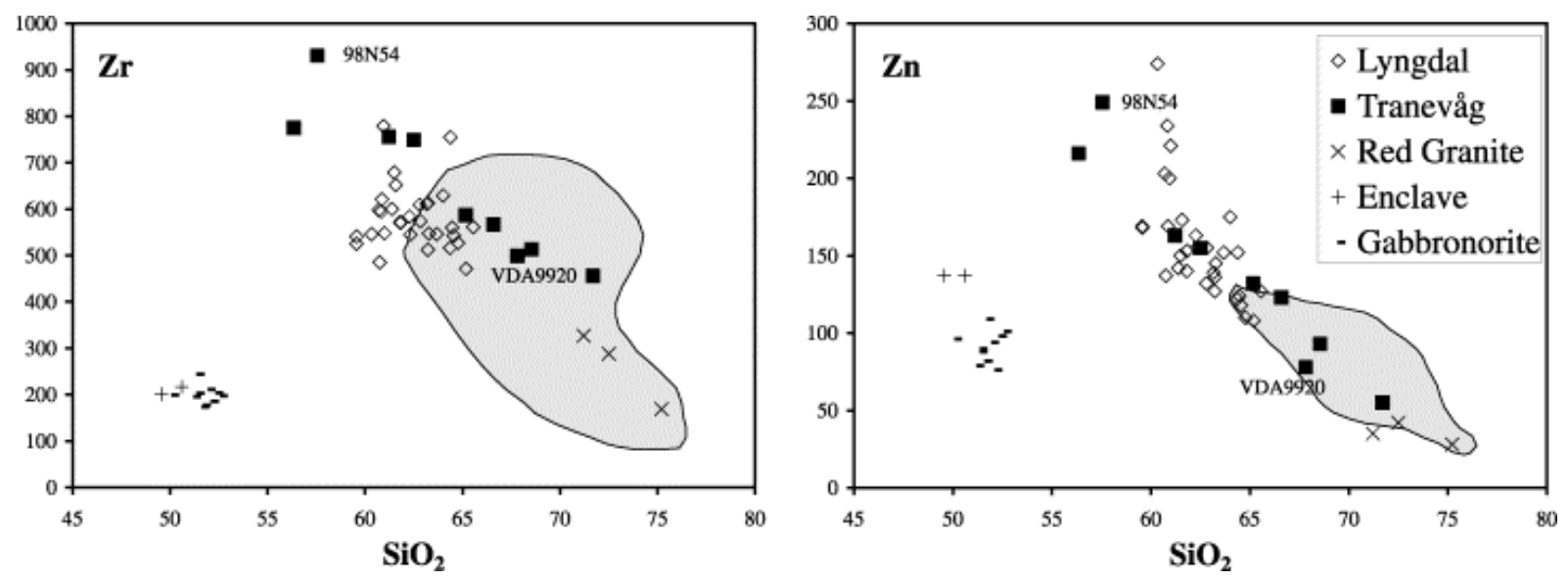

Fig. 9. Trace element content (ppm) vs. wt.\% $\mathrm{SiO}_{2}$. 

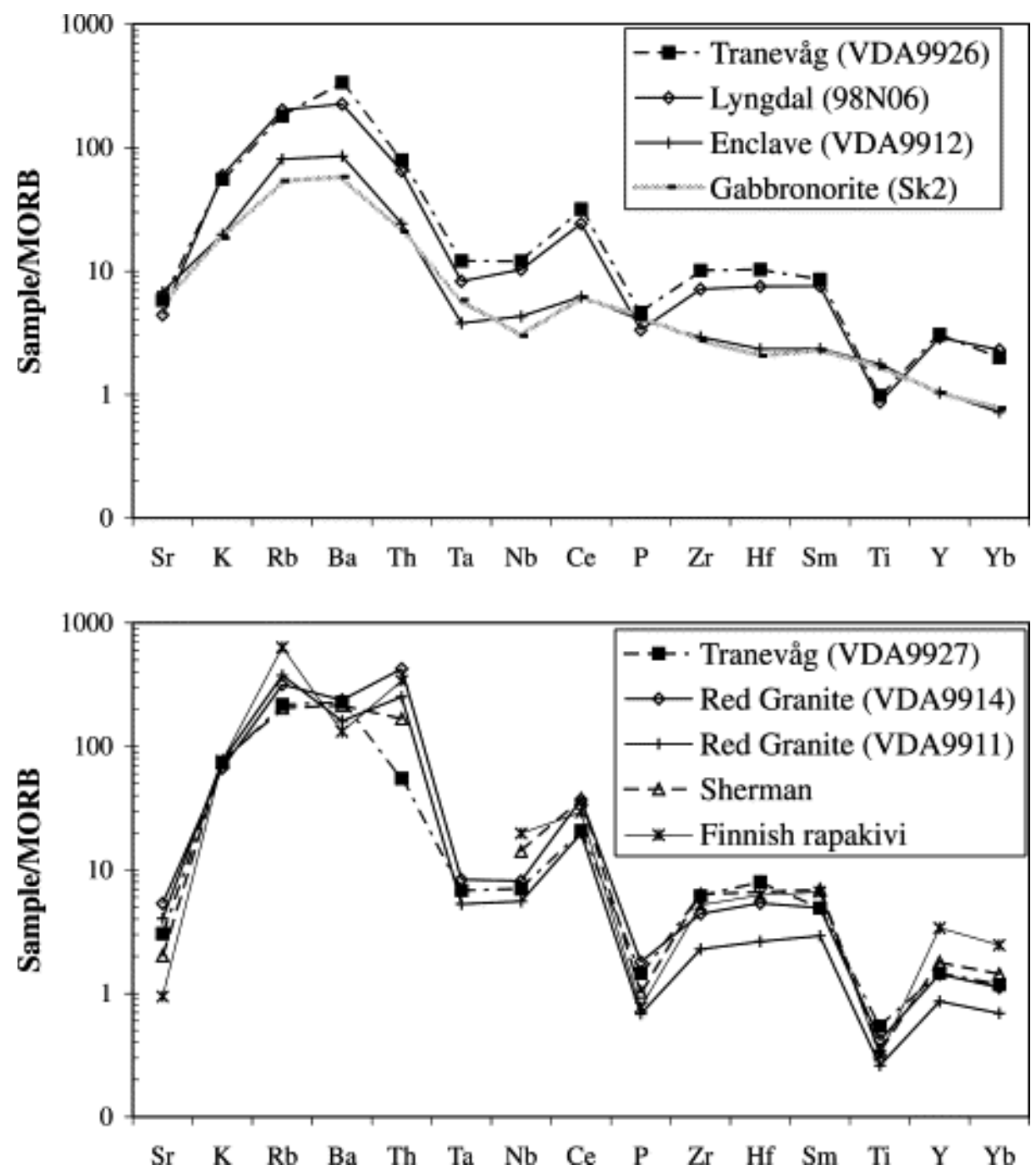

Fig. 10. MORB-normalised diagram (normalisation values from Sun and McDonough, 1989). Data for the Finnish rapakivi are from Rämö and Haapala (1995) and for the Sherman granite (sample 91smw28) from Frost et al. (1999). 

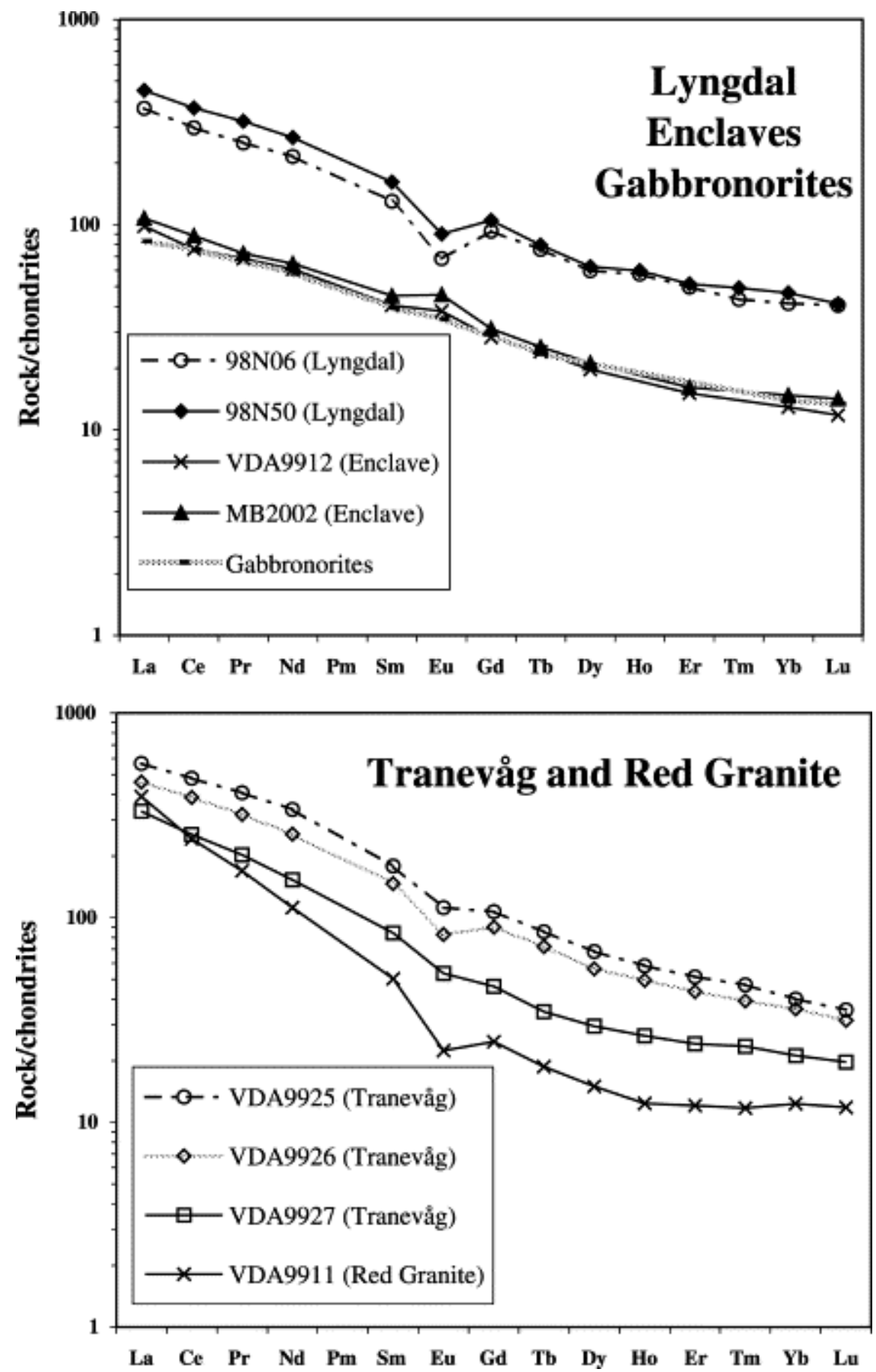

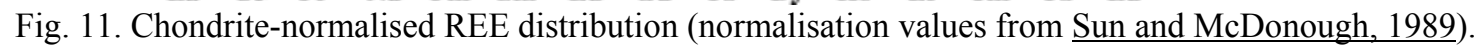

The Lyngdal-Tranevåg trend (from 56.3 to $71.7 \% \mathrm{SiO}_{2}$ ) belongs to the HBG trend (Vander Auwera et al., 2003) which continuously ranges from the gabbronorites $\left(50 \% \mathrm{SiO}_{2}\right)$ to granites $\left(76.6 \% \mathrm{SiO}_{2}\right)$. In this paper, we only discuss the differentiation process for Lyngdal, Tranevåg and the Red Granite. The evolution of the HBG trend from the gabbronorites is discussed in Vander Auwera et al. (2003). We have, however, plotted the shape of the HBG trend in the $\mathrm{Sr}$ versus $\mathrm{SiO}_{2}$ diagram because samples from the Lyngdal and Tranevåg plutons are scattered for this element (even neglecting sample VDA9920), particularly for the least differentiated samples (98N54 and VDA9925). This diagram shows that sample VDA9925 plots on the HBG trend while the low-Sr content of $98 \mathrm{~N} 54$, coupled with its low Ba and 
$\mathrm{Eu} / \mathrm{Eu}^{*}(0.37$ against $0.65-1.01$ for all other samples) is probably due to substracted feldspar. Sample VDA9925 is then used for representing the least differentiated composition of the Lyngdal-Tranevåg trend. The Lyngdal-Tranevåg trend and the Red Granite overlap with the rapakivi granites and extend their field to lower $\mathrm{SiO}_{2}$ content (ig. 8 and Fig. 9). Trace elements for rapakivi granites ( $\underline{\text { Fig. } 9}$ ) are widely scattered but they always display the same pattern in normalised multi-element diagrams, as illustrated in Fig. 10. In Norway, the intermediate composition (granodioritic) dominates over granites unlike in the Proterozoic rapakivi granite provinces.

\subsection{Results for mafic microgranular enclaves}

The studied mafic microgranular enclaves have a basaltic composition rich in $\mathrm{Al}_{2} \mathrm{O}_{3}$ (16 wt.\%) and $\mathrm{TiO}_{2}(2.25 \mathrm{wt} . \%)$. These enclaves have a major and trace elements (Fig. 8 and Fig. 9) composition close to the gabbronorites ( Demaiffe et al., 1990), with slightly lower $\mathrm{Al}_{2} \mathrm{O}_{3}$ and $\mathrm{CaO}$ content and higher $\mathrm{Fe}_{2} \mathrm{O}_{3 \mathrm{t}}$ and $\mathrm{Na}_{2} \mathrm{O}$ content. They display same REE patterns (Fig. 11) with positive Eu anomaly (1.89 and 1.10 for the mafic enclaves). In a MORBnormalised diagram ( Fig. 10), mafic microgranular enclaves and gabbronorites have a smoother pattern than granitoids, with only a weak negative anomaly in $\mathrm{Nb}-\mathrm{Ta}$.

\section{Sr-Nd isotopic compositions}

Seven samples from the Lyngdal granodiorite, five samples from the Tranevåg massif, one sample from the Red Granite and one mafic enclave sample have been selected for $\mathrm{Sr}$ and $\mathrm{Nd}$ isotopic analyses. Strontium and neodymium isotopic data are presented in Table 5.

Table 5. Sr and $\mathrm{Nd}$ isotopes

$\mathrm{E}_{\mathrm{Nd}}$ are calculated relative to CHUR with the present value of ${ }^{143} \mathrm{Nd} /{ }^{144} \mathrm{Nd}=0.512638$ (Goldstein et al., 1984) and ${ }^{147} \mathrm{Sm} /{ }^{143} \mathrm{Nd}=0.1967$ (Jacobsen and Wasseburg, 1980). $\mathrm{T}_{\mathrm{DM}}$ (depleted mantle model ages) are calculated following parameters of Nelson and DePaolo (1985).

A Rb-Sr isochron (calculations after Ludwig, 2001) has been obtained for the Tranevåg and Red Granite massifs $\left(953 \pm 26 \mathrm{Ma}\right.$, initial ${ }^{87} \mathrm{Sr} /{ }^{86} \mathrm{Sr}=0.70409 \pm 0.00017, \mathrm{MSWD}=1.09$, six whole rocks, Fig. 12). The Red Granite and sample VDA9920 being out of the Lyngdal-Tranevåg trend for some elements (Fig. 9 and Fig. 10) as well as for the $\mathrm{Nd}$ isotopic composition (see the following), the isochron built with all these samples is questionable. An isochron for the sole Tranevåg massif (except sample VDA9920) is also obtained, with an age similar to the combined Tranevåg-Red Granite isochron $\left(963 \pm 31 \mathrm{Ma}\right.$, initial ${ }^{87} \mathrm{Sr} /{ }^{86} \mathrm{Sr}=0.70404 \pm 0.00019$, $\mathrm{MSWD}=1.4$, four whole rocks). 

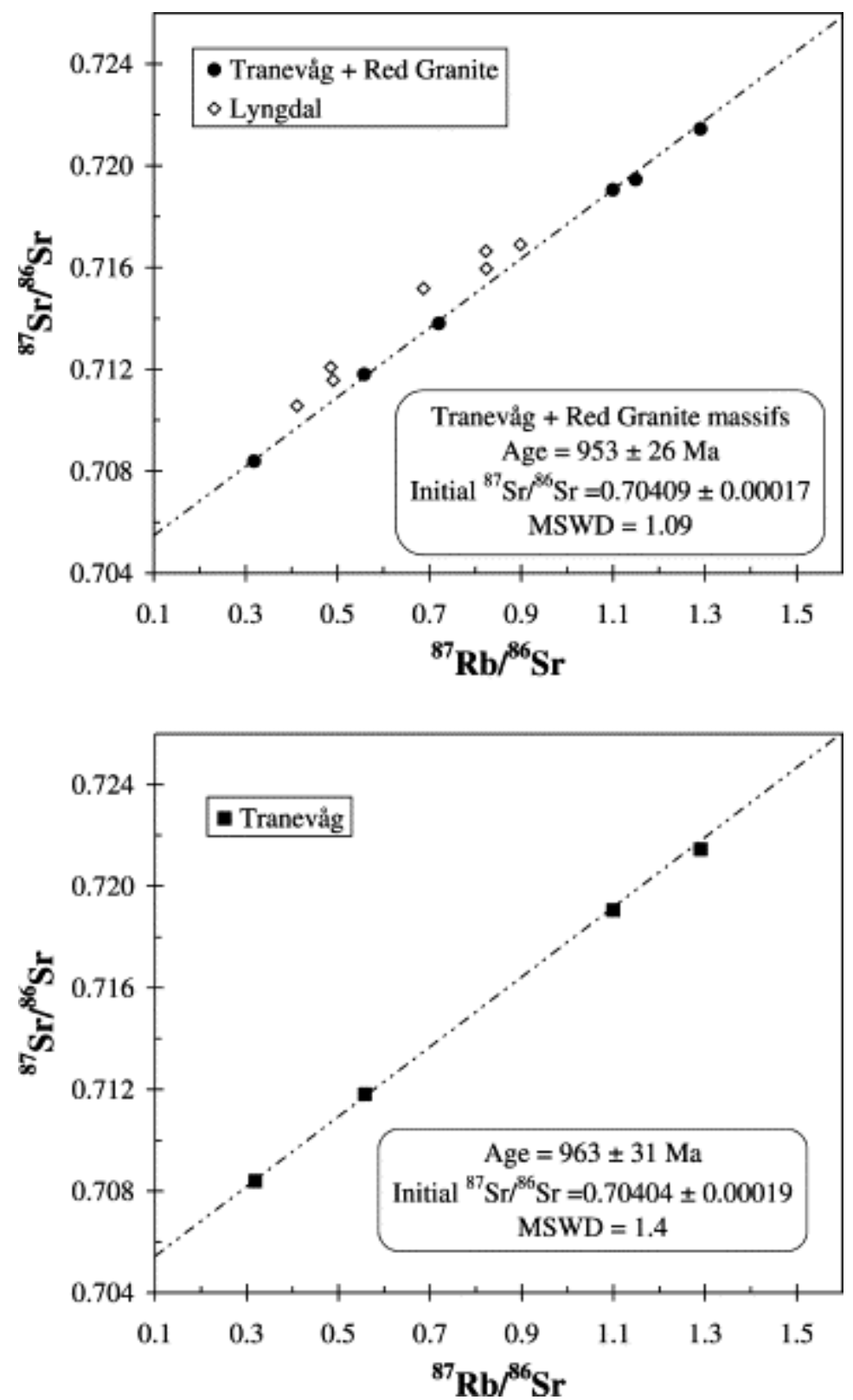

Fig. 12. Rb-Sr isochrons.

The Lyngdal granodiorite displays an errorchron $(937 \pm 170 \mathrm{Ma}$, initial ${ }^{87} \mathrm{Sr} /{ }^{86} \mathrm{Sr}=0.7054 \pm 0.0017, \mathrm{MSWD}=6.4$, seven whole rocks). An age of $932 \pm 38 \mathrm{Ma}$ (initial ${ }^{87} \mathrm{Sr} /{ }^{86} \mathrm{Sr}=0.7054 \pm 0.0005, \mathrm{MSWD}=0.43$, six whole rocks) was given by Pedersen and Falkum (1975). However, recalculated with the Ludwig's program this gives: $899 \pm 87 \mathrm{Ma}$ (initial ${ }^{87} \mathrm{Sr} /{ }^{86} \mathrm{Sr}=0.7055 \pm 0.0010, \mathrm{MSWD}=2.6$, six whole rocks, Model 1) or $886 \pm 79 \mathrm{Ma}$ (Model 3). Grouped with the samples from this study, this gives: $929 \pm 57 \mathrm{Ma}$ (initial ${ }^{87} \mathrm{Sr} /{ }^{86} \mathrm{Sr}=0.70531 \pm 0.00079$, MSWD $=5.1$, fourteen whole rocks). This $\mathrm{Rb}-\mathrm{Sr}$ age of $929 \pm 57 \mathrm{Ma}$ is similar within error limits to the $\mathrm{U}-\mathrm{Pb}$ age obtained by the U-Pb method

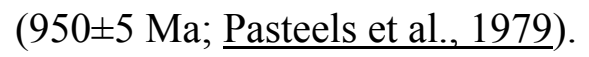

Isotopic compositions have been recalculated at $950 \mathrm{Ma}\left(\mathrm{U}-\mathrm{Pb}\right.$ age; Fig. 13). The ${ }^{87} \mathrm{Sr} /{ }^{86} \mathrm{Sr}_{\mathrm{i}}$ ratio of Lyngdal ranges between 0.7047 and 0.7058 , being systematically slightly higher than the ${ }^{87} \mathrm{Sr} /{ }^{86} \mathrm{Sr}_{\mathrm{i}}$ ratios of the Tranevåg $(0.7039-0.7042)$ and Red Granite $(0.7038)$ massifs. The analysed MME has ${ }^{87} \mathrm{Sr}^{86} \mathrm{Sr}_{\mathrm{i}}=0.7038$. Nd isotopic compositions at $950 \mathrm{Ma}$ vary from $\varepsilon$ $\mathrm{Nd}=+0.65(\mathrm{MME})$ to -3.36 . $\varepsilon_{\mathrm{Nd}}$ from Lyngdal and Tranevåg granitoids are restricted to the 
range -0.78 to -2.74 . The slightly positive $\varepsilon_{\mathrm{Nd}}$ of the MME $(+0.68)$ is comparable to the $\varepsilon_{\mathrm{Nd}}$ calculated at $950 \mathrm{Ma}(+0.4 /+1.9)$ for the gabbronorites (Demaiffe et al., 1990). The isotopic composition of the Lyngdal complex is identical to the other HBG granitoids ( Fig. 13) and is clearly distinct in $\mathrm{Sr}_{i}$ from the country-rocks. Isotopic initial ratios within a single massif are relatively constant whatever the silica content (Fig. 13) even if variations exceed analytical errors, particularly for $\varepsilon_{\mathrm{Nd}}$. A major observation is the decoupling between $\mathrm{Sr}$ and $\mathrm{Nd}$ isotopic initial ratios when comparing the gabbronorites and the granitoids: between 50 and $73 \mathrm{wt} \%$ $\mathrm{SiO}_{2}, \mathrm{Sr}_{\mathrm{i}}$ varies from 0.7038 to 0.7058 , the variation being linked to plutons and not to silica. In other words, the gabbronorites display the same $\mathrm{Sr}_{\mathrm{i}}$ range than the granitoids. Taking into account the sole granitoids, there is no $\varepsilon_{\mathrm{Nd}}$ variation with $\mathrm{SiO}_{2}$. This also holds for the other HBG granitoids (Vander Auwera et al., 2003): as for Sr, the spread of $\varepsilon_{\mathrm{Nd}}$ is linked to plutons and not to silica. However, in contrast with $\mathrm{Sr}_{\mathrm{i}}, \varepsilon_{\mathrm{Nd}}$ for the gabbronorites is positive (as for the MME) while the $\varepsilon_{N d}$ for the granitoids is negative, as previously said. The result in the $\varepsilon_{\mathrm{Nd}}$ versus $\mathrm{Sr}_{\mathrm{i}}$ diagram (Fig. 13) is a trend roughly parallel to the $\mathrm{Y}$ axis. This could suggest a $\mathrm{Rb}-$ depleted lower crust either as a heterogeneous source or as a contaminant for a juvenile differentiating magma through an AFC (assimilation-crystal fractionation; DePaolo, 1981) process. Vander Auwera et al. (2003) propose that the HBG granitoids are differentiation products from gabbronorites. In this case, contamination had to occur during the differentiation from the gabbronorites to the quartz monzodiorites. 

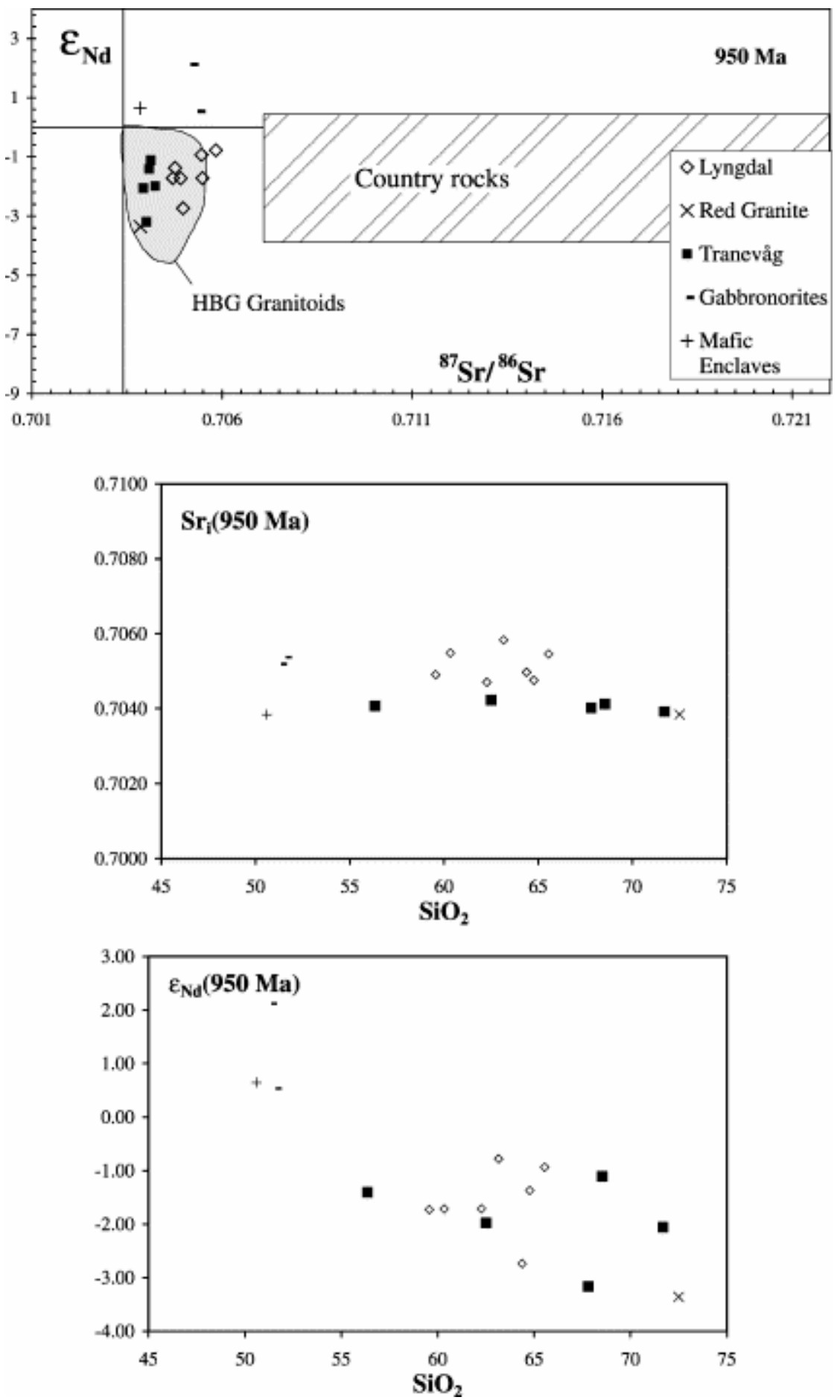

Fig. 13. Sr and $\mathrm{Nd}$ isotopic compositions calculated back to $950 \mathrm{Ma}$. Data for the HBG granitoids are from

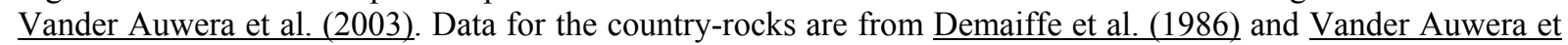
al. (2003).

Most of the $\mathrm{T}_{\mathrm{DM}}$ (Table 5) vary between 1440 and $1580 \mathrm{Ma}$ (with two additional samples at 1646 and $1707 \mathrm{Ma}$ ). This suggests a ca. $1.55 \mathrm{Ga}$ age for a lower crustal source, and an age a little bit older for a lower crustal contaminant ( $\mathrm{T}_{\mathrm{DM}}$ being in this case mixed model ages between the juvenile source and the older contaminant). The actual gneissic country-rocks have played no role in the Lyngdal plutons genesis, their ${ }^{87} \mathrm{Sr} /{ }^{86} \mathrm{Sr}$ composition at $950 \mathrm{Ma}$ are by far too high (Fig. 13). 


\section{Discussion}

\subsection{The mafic microgranular enclaves}

Several models have been proposed for the origin of mafic microgranular enclaves: (1) the enclaves are restite (White and Chappell, 1977 and Chappell et al., 1987), (2) the enclaves are cognate cumulates (e.g. Dodge and Kistler, 1990), (3) they are mafic magma injected in a felsic magma chamber ( Huppert and Sparks, 1988 and Eberz et al., 1990). Field and petrographical observations suggest that the mafic microgranular enclaves have a magmatic origin. Moreover, they have isotopic and geochemical compositions similar to the coeval gabbronorites ( Demaiffe et al., 1990). These two observations strongly favour the hypothesis that the microgranular enclaves are remnants of mafic injections in a felsic magma. Enclaves are, however, slightly richer in $\mathrm{Na}, \mathrm{Rb}, \mathrm{K}, \mathrm{Fe}, \mathrm{Zn}, \mathrm{Mn}$ and lower in $\mathrm{Ca}$ and $\mathrm{Al}$ than the gabbronorites, indicating that chemical exchange may have occurred between the enclaves and its host magma, as often observed. An additional, major, difference exists between the enclaves and the gabbronorites: the ferromagnesian minerals are amphibole and biotite in the enclaves and pyroxenes in the gabbronorites. The presence of hydrous minerals in the enclaves could be due to a higher $\mathrm{H}_{2} \mathrm{O}$-content of the magma before it mingled with the granitic magma. Alternatively, water may have been incorporated from the host granitic magma into the enclaves such that the stability field of hydrous minerals was enhanced at the expense of the mafic anhydrous minerals (Barbarin and Didier, 1992).

\subsection{The granitoids}

Fig. 8, Fig. 9 and Fig. 10 show that the most felsic samples (above 63 wt.\% $\mathrm{SiO}_{2}$ ) of the Lyngdal-Tranevåg trend are very similar to Proterozoic metaluminous A-type granites (rapakivi granites). The main processes proposed for the generation of A-type granite magmas are (1) vapor-absent melting in the lower crust of a melt-depleted (Collins et al., 1982 and Clemens et al., 1986) or of a primitive igneous protolith ( Anderson and Bender, 1989; Creaser et al., 1991; Emslie et al., 1994 and Dall'Agnol et al., 1999b, Frost et al., 1999) and (2) differentiation from a mantle magma with or without crustal contamination ( Barker et al., 1975; Turner et al., 1992; Tack et al., 1994 and Duchesne et al., 1998). Authors studying Proterozoic rapakivi granites favour a crustal source ( Rämö and Haapala, 1995). For instance, the protolith of the Jamon Granite, which is similar to the granitic samples of the Lyngdal-Tranevåg trend and which has similar $\mathrm{fO}_{2}$ and $\mathrm{H}_{2} \mathrm{O}$ content (Dall'Agnol et al., 1999b and Bogaerts et al., 2001), is believed to be an Archean quartz diorite ( Dall'Agnol et al., $1999 \mathrm{c})$. However, the Lyngdal complex differs from the other Proterozoic granitoids by the overwhelming proportion of granodioritic rocks over granites. In the following, we first need to discuss the origin of the Lyngdal-Tranevåg trend to test whether studied granites can be derived from dioritic to granodioritic magmas.

\subsubsection{Origin of the Lyngdal-Tranevåg trend}

The linear or pseudo-linear trends displayed by the granitoids could have been produced by: (1) restite unmixing, (2) mixing between two magmas, (3) partial melting, (4) crystal fractionation.

\subsubsection{Restite unmixing}


Mafic microgranular enclaves and relics of pyroxene in amphiboles have been interpreted as evidence of restites in granitoids by White and Chappell (1977) and Chappell et al. (1987). However, the mafic microgranular enclaves have the composition of coeval mafic magmatic rocks (gabbronorites), which suggests a magmatic origin. Secondly, the compositions of the ferromagnesian minerals, and more precisely of clinopyroxene, have been reproduced in a series of crystallisation experiments performed on two samples from Lyngdal ( Bogaerts et al., 2001). We thus do not favour a differentiation process by restite disposal.

\subsubsection{Mixing}

Mingling and mixing are common processes in the Proterozoic rapakivi granitoids. For instance, in the Åland rapakivi batholith (Eklund et al., 1994), mingling and mixing between a monzodiorite, derived from a norite-anorthosite-monzodiorite series and a felsic magma produced by the partial melting of the country-rocks, give a magma of intermediate composition. Salonsaari and Haapala (1994) showed that hornblende granodiorite in the JaalaIitti Rapakivi complex, whose composition is similar to Lyngdal, is produced by mixing/mingling between a basic mantle-derived magma and a 'rapakivi' granitic melt. In the Lyngdal complex mingling between granite and gabbronorites has been observed (see Section 7.1). However, the gabbronorites and mafic enclaves do not define a mixing line with the granitic samples in the Harker diagrams ( Fig. 8 and Fig. 9) so that there is no geochemical evidence for a mixing between gabbronorites and granites nor between gabbronorites and quartz monzodiorites. Mixing between quartz monzodiorite sample (e.g. VDA9925) and granitic samples can be assessed in view of the pseudo-linear trend displayed by the granitoids. As seen in the preceding section, the Red Granite, as well as sample VDA9920, are out of the Lyngdal-Tranevåg trend and are not considered as a possible felsic component. The two end-members of the Tranevåg trend (VDA9925 and VAD9927) have similar Nd and $\mathrm{Sr}$ isotopic composition $\left({ }^{87} \mathrm{Sr} /{ }^{86} \mathrm{Sr}_{(950 \mathrm{Ma})}\right.$ : +0.7040 and $0.7039 ; \mathrm{E}_{\mathrm{Nd}(950 \mathrm{Ma})}:-1.41$ and -2.05 , respectively for VDA9925 and VDA9927) suggesting a same source. Moreover, simple two end-members mixing between the mafic (VDA9925) and the felsic sample (VDA9927) can be tested to obtain the intermediate rock (VDA9926) by using a binary mixing equation (Fourcade and Allègre, 1981):

$C_{m}{ }^{i}-C_{a}{ }^{i}=X\left(C_{b}{ }^{i}-C_{a}{ }^{i}\right)$

where $C_{a}{ }^{i}, C_{b}{ }^{i}$ and $C_{m}{ }^{i}$ are the concentrations of the element $i$ in the felsic, mafic and mixed melt, respectively and $X$ is the proportion of the mafic component. In Fig. 14, all possible mixed compositions have to fall on a straight line between $X=0$ and $X=1$, which is clearly not the case. Moreover, some elements are near $X=1$ (e.g. $\mathrm{Zr}$ and $\mathrm{Y}$ ) and $\mathrm{Ba}$ is out of the possible domain. It could be argued that some crystallisation of minerals like zircon, plagioclase and biotite has accompanied mixing and acted to deviate $\mathrm{Zr}, \mathrm{Y}, \mathrm{Sr}$ and $\mathrm{Ba}$ from the mixing curve. But in this case, all those elements should be depleted relative to the mixing curve, and this is not supported by the data for $\mathrm{Zr}, \mathrm{Y}$ and Ba. Mixing does not appear to be the dominant mechanism of magma fractionation in Lyngdal and associated plutons. 


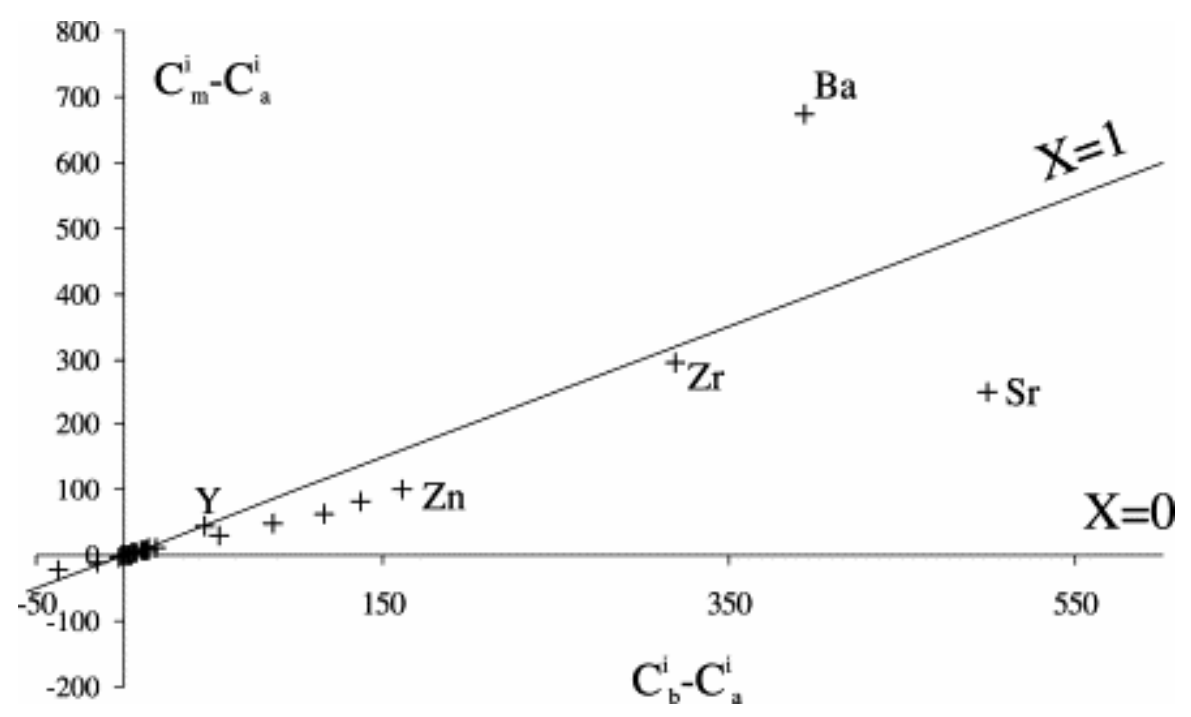

Fig. 14. Results of mixing calculations. $C_{a}, C_{b}$ and $C_{m}$ are the concentrations in the felsic, mafic and mixed melt. $X$ is the proportion of the mafic components in the mixing.

\subsubsection{Partial melting/fractional crystallisation}

Batch partial melting and fractional crystallisation can be distinguished by plotting an incompatible versus a compatible element in a $\log -\log$ diagram (e.g. Martin, 1987). Rb and $\mathrm{Sr}$ are, respectively incompatible and compatible as in the Harker diagrams $\mathrm{Sr}$ decreases and $\mathrm{Rb}$ increases with $\mathrm{SiO}_{2}$ (Fig. 9). We selected $\mathrm{Sr}$ because it is not significantly accommodated in accessory minerals (e.g. oxides, zircon) unlike other compatible elements (such as $\mathrm{Y}, \mathrm{Zr}$ or $\mathrm{Zn}$ ), that will greatly simplify the following modelling. In the hypothesis that the LyngdalTranevåg trend is due to batch partial melting, the low-silica samples of this trend should represent melts derived from higher degree of partial melting than the high-silica samples as the melt content in $\mathrm{Fe}, \mathrm{Mg}$ and Ti elements increases with temperature. Melting of different crustal protoliths under fluid-absent conditions (e.g. Beard et al., 1994 and Rapp and Watson, 1995) has shown that plagioclase is a common restitic mineral. In this case, the source must be very rich in $\mathrm{Sr}$ (and $\mathrm{SiO}_{2}$ poor) as the melt gets close to the composition of the source with an increasing degree of melting. Roberts and Clemens (1993 and references therein) argue that there is a positive correlation between the $\mathrm{K}_{2} \mathrm{O}$ content in the magma and the $\mathrm{K}_{2} \mathrm{O}$ content in its source. In other words, if a magmatic suite has a crustal origin with a given $\mathrm{K}_{2} \mathrm{O}$ content (e.g. low-K, medium- $\mathrm{K}$ or high- $\mathrm{K}$ fields), its source plot in the same $\mathrm{K}_{2} \mathrm{O}-\mathrm{SiO}_{2}$ field. This means that, if the Lyngdal-Tranevåg differentiation trend is due to a partial melting process, the source of this magmatic suite probably plots in the same field, i.e. in the HKCA field of Peccerillo and Taylor (1976). In the Rogaland-Vest Agder sector, mafic protoliths from the augen gneisses suite (see Section 3.1.) could represent such $\mathrm{Sr}$ and K-rich rocks. The augen gneisses define a HKCA suite and their Sr content can be higher than $1000 \mathrm{ppm}$ in the mafic terms $\left(<57 \mathrm{wt} . \% \mathrm{SiO}_{2}\right)$ of this suite (Bingen, 1989). Moreover, their $\mathrm{Nd}$ and $\mathrm{Sr}$ isotopic compositions at $950 \mathrm{Ma}$ is similar to the HBG granitoids. The mafic terms of the augen gneisses suite are thus a suitable source to test the hypothesis of a differentiation by partial melting for the Lyngdal-Tranevåg trend. To model the batch melting process, we used the Schilling and Winchester (1967) equation :

$$
C_{L}^{i}=\frac{C_{0}^{i}}{D+F(1-D)}
$$


$C_{L}$ and $C_{0}$ are the concentrations of an element $i$ in the melt and in the protolith, respectively and $F$ is the weight fraction of the melt produced by batch melting. $D$ is the bulk partition coefficient between the melt and the residual solid for the element $i$ :

$$
D=\sum_{j} X_{j} K_{d}^{j / \text { melt }}
$$

The $X_{j}$ is the weight fraction of a mineral jin the restite and $K_{d}$ is the partition coefficient for the element $i$ between the mineral $j$ and the melt. We have taken the $\mathrm{Rb}$ and $\mathrm{Sr}$ contents of the protolith $(\mathrm{Rb}=80 \mathrm{ppm}$ and $\mathrm{Sr}=1000 \mathrm{ppm})$ from the data on the augen gneisses (Bingen, 1989). The $X_{j}$ ( $X_{\text {plagioclase }}=0.5$ and $X_{\mathrm{cpx}}=0.5$ ignoring minor minerals like oxides) are estimated from the data on dehydration melting of basalts taken in Rapp and Watson (1995). The partition coefficients used and references are given in the Appendix A. They are valid for melts of intermediate to rhyolitic compositions. With these parameters, we get $D_{\mathrm{Rb}}=0.16$ and $D_{\mathrm{Sr}}=2$. The data of the Lyngdal-Tranevåg trend are not well reproduced by batch partial melting (Fig. 15), even by varying $D_{\mathrm{Sr}}$ (between 3.5 and 1.5). By opposition, they are well fitted by the fractional crystallisation modelling (a straight line in a log-log diagram) with $D_{\mathrm{Rb}}=0.4$ and $D_{\mathrm{Sr}}=2.5$. We thus favour this latter process to explain our trend.

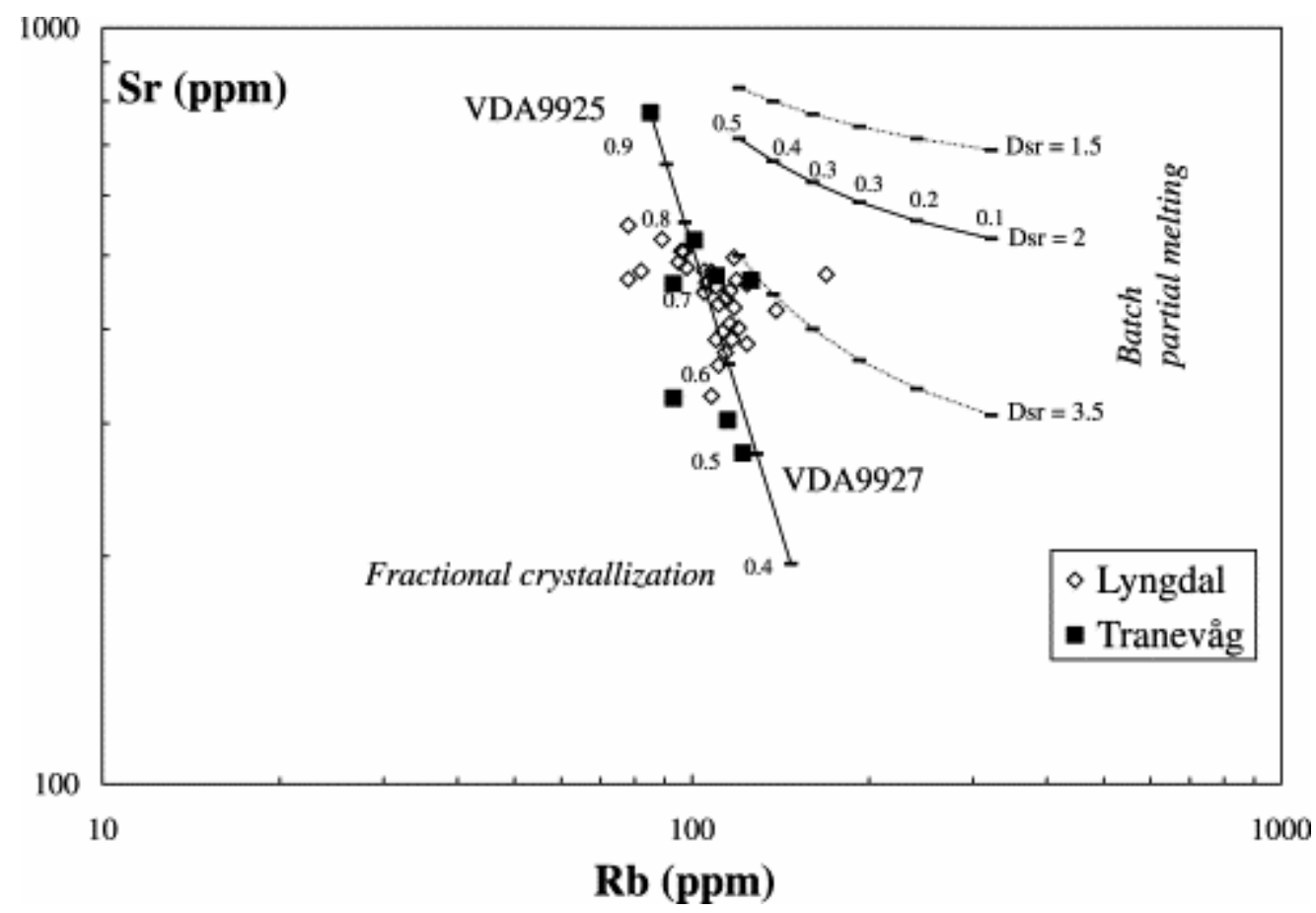

Fig. 15. Sr vs. Rb diagram (logarithmic scale). Curves show the batch partial melting (for three different $D_{\mathrm{Sr}}$ ) and the fractional crystallisation models. Numbers along curves refer to the degree of partial melting and the degree of crystallisation. See text for explanation. 
The absence of correlation between $\mathrm{SiO}_{2}$ (or other elements with crustal affinity like $\mathrm{Rb}$ ) and $\mathrm{Sr}_{\mathrm{i}}$ or $\varepsilon_{\mathrm{Nd}}$ (Fig. 13) suggests that assimilation of country rock is of minor importance during the differentiation from quartz monzodiorites to granites (see Section 6).

\subsubsection{Modelling of a liquid line of descent}

In order to better test and quantify the fractional crystallisation process, mass-balance calculations were performed using the least-squares method (e.g. Martin, 1987). The liquid line of descent from quartz monzodiorite to granite has been modelled in two stages. Stage 1 starts with the least differentiated sample of Tranevåg at 56 wt.\% $\mathrm{SiO}_{2}$ (VDA9925) to give a residual melt of $62.5 \mathrm{wt} . \% \mathrm{SiO}_{2}$ (VDA9926) and stage 2 starts from the latter sample to give a residual melt of $72 \mathrm{wt} . \% \mathrm{SiO}_{2}$ (VDA9927). These three samples encompass the entire Lyngdal-Tranevåg trend. The nature and the composition of the fractionated minerals are those from the natural rocks or from experimental data acquired on two rocks from the Lyngdal granodiorite (98N50 with $\mathrm{SiO}_{2} 59$ wt.\% and 98N06 with $\mathrm{SiO}_{2} 65$ wt.\%). The pressure of the experiments is $4 \mathrm{kbar}$ and $f \mathrm{O}_{2}$ between $\mathrm{NNO}$ and $\mathrm{NNO}+1$ (Bogaerts et al., 2001). As the compositions of experimental plagioclase and amphibole are very similar in the two starting products, identical plagioclase and hornblende compositions were used for the modelling of the two stages. The results of the least-squares modelling are given in Table 6 . There are two possible models for stage 1 . The fractionating minerals are clinopyroxene, plagioclase, magnetite, ilmenite and apatite with (Model 1) or without (Model 2) hornblende. The sums of the squared residual are low (Table 6) and the percentage of crystallisation is similar for the two models (32\%). Trace elements are used to check the two models with the Rayleigh equation :

$$
\frac{C_{L}^{i}}{C_{0}^{i}}=F^{(D-1)}
$$

This equation describes the evolution of a trace element $i$ during fractional crystallisation. $D$ is the bulk partition coefficient for the element $i$ and $F$ is the proportion of residual melt. $C_{0}{ }^{i}$ is the initial content of the element $i$ in the melt and $C_{L}{ }^{i}$ is the content of $i$ in the residual melt. Mineral-melt partition coefficients are given in the Appendix A and the results of the modelling are given in Table 7. The effect of zircon fractionation can be very important on HREE and need to be accounted for. The proportion of fractionating zircon is calculated with the mass-balance equation, assuming that all $\mathrm{Zr}$ is accommodated by the zircon. The proportion of subtracted zircon is $0.17 \%$ for stage 1 . Good results can be obtained for the two models, and due to the absence of better constraints on the values of partition coefficients, trace elements cannot neither discriminate between the two models. 


\begin{tabular}{|c|c|c|c|c|c|c|c|c|c|c|c|c|c|c|c|c|}
\hline & $\begin{array}{l}\text { VDA9925 } \\
\text { parent }\end{array}$ & $\begin{array}{l}\text { VDA9926 } \\
\text { observed }\end{array}$ & $\begin{array}{l}\text { Model } 1 \\
\text { calculated }\end{array}$ & $\begin{array}{l}\text { Model } 2 \\
\text { calculated }\end{array}$ & $\begin{array}{l}\text { VDA9926 } \\
\text { parent }\end{array}$ & $\begin{array}{l}\text { VDA9927 } \\
\text { observed }\end{array}$ & $\begin{array}{l}\text { Model 3 } \\
\text { calculated }\end{array}$ & Cpx & $\mathrm{Hbl}$ & Plag & Mgt & Ilm & Apatite & Biotite & $\begin{array}{l}\text { Percentage of } \\
\text { crystallisation }\end{array}$ & $\sum \mathrm{r}^{2}$ \\
\hline$\overline{\mathrm{SiO}_{2}}$ & 56.34 & 62.50 & 62.52 & 62.34 & 62.50 & 71.69 & 71.49 & 51.88 & 41.82 & 60.16 & 0.00 & 0.00 & 0.00 & 36.62 & & \\
\hline $\mathrm{TiO}_{2}$ & 1.89 & 1.25 & 1.25 & 1.12 & 1.25 & 0.69 & 0.65 & 0.17 & 2.14 & 0.00 & 12.10 & 45.12 & 0.00 & 3.71 & & \\
\hline $\mathrm{Al}_{2} \mathrm{O}_{3}$ & 14.01 & 14.20 & 14.19 & 14.28 & 14.20 & 13.45 & 13.32 & 1.24 & 10.98 & 23.71 & 2.25 & 0.32 & 0.00 & 14.00 & & \\
\hline $\mathrm{FeO}$ & 9.71 & 6.71 & 6.72 & 6.59 & 6.71 & 2.91 & 2.87 & 12.29 & 16.58 & 0.61 & 76.79 & 47.60 & 0.00 & 21.17 & & \\
\hline $\mathrm{MnO}$ & 0.20 & 0.12 & 0.22 & 0.20 & 0.12 & 0.05 & 0.12 & 0.69 & 0.28 & 0.00 & 0.29 & 0.33 & 0.00 & 0.21 & & \\
\hline $\mathrm{MgO}$ & 2.25 & 1.48 & 1.49 & 2.00 & 1.48 & 0.59 & 0.51 & 11.23 & 11.07 & 0.00 & 1.19 & 2.10 & 0.00 & 11.33 & & \\
\hline $\mathrm{CaO}$ & 5.79 & 3.88 & 3.84 & 3.56 & 3.88 & 1.53 & 1.59 & 22.48 & 11.08 & 6.75 & 0.00 & 0.00 & 55.80 & 0.10 & & \\
\hline $\mathrm{Na}_{2} \mathrm{O}$ & 3.51 & 3.52 & 3.51 & 3.42 & 3.52 & 3.13 & 3.28 & 0.60 & 1.91 & 6.56 & 0.00 & 0.00 & 0.00 & 0.07 & & \\
\hline $\mathrm{K}_{2} \mathrm{O}$ & 2.85 & 3.99 & 3.88 & 4.00 & 3.99 & 5.33 & 5.46 & 0.00 & 0.81 & 1.01 & 0.00 & 0.00 & 0.00 & 9.25 & & \\
\hline $\mathrm{P}_{2} \mathrm{O}_{5}$ & 0.88 & 0.54 & 0.58 & 0.68 & 0.54 & 0.17 & 0.12 & 0.00 & 0.00 & 0.00 & 0.00 & 0.00 & 44.20 & 0.00 & & \\
\hline \multirow{4}{*}{$\begin{array}{l}\text { Stage } 1 \text { (VDA9925 } \\
\Rightarrow \text { VDA9926) }\end{array}$} & & & & & & & Model 1 & & & & & & & & 30.99 & 0.013 \\
\hline & & & & & & & $\mathrm{Xi} * 100$ & 12.53 & 22.23 & 47.14 & 11.67 & 2.85 & 3.57 & & & \\
\hline & & & & & & & Model 2 & & & & & & & & 32.56 & 0.22 \\
\hline & & & & & & & $\mathrm{Xi} * 100$ & 23.42 & & 55.87 & 14.12 & 3.60 & 2.99 & & & \\
\hline \multirow{6}{*}{$\begin{array}{l}\text { Stage } 2 \text { (VDA9926 } \\
\Rightarrow \text { VDA9927) }\end{array}$} & & & & & & & Model 1 & & & & & & & & 32.07 & 0.059 \\
\hline & & & & & & & $\mathrm{Xi}^{*} 100$ & & 30.57 & 53.99 & 10.67 & 1.1 & 3.67 & & & \\
\hline & & & & & & & Model 2 & & & & & & & & 32.11 & 0.047 \\
\hline & & & & & & & $\mathrm{X}+100$ & & 28.12 & 54.07 & 10.76 & 0.86 & 3.82 & 2.36 & & \\
\hline & & & & & & & Model 3 & & & & & & & & 37.09 & 0.07 \\
\hline & & & & & & & $\mathrm{Xi} * 100$ & 4.66 & 10.97 & 59.80 & 9.92 & 1.05 & 2.64 & 10.16 & & \\
\hline
\end{tabular}

Table 6. Results of mass-balance calculations for major elements

In italic: experimental mineral composition (Bogaerts et al., 2001). Mineral abbreviations: Cpx, clinopyroxene; Hbl, hornblende; Plag, plagioclase; Mgt, magnetite; Ilm, ilmenite.

\begin{tabular}{|c|c|c|c|c|c|c|c|c|c|c|}
\hline & $\begin{array}{l}\text { VDA9925 } \\
\text { C0 }\end{array}$ & $\begin{array}{l}\text { Calculated } \\
\mathrm{Cl} \text { (Model 1) }\end{array}$ & $\begin{array}{l}\text { Calculated } \\
\mathrm{Cl} \text { (Model 2) }\end{array}$ & $\begin{array}{l}\text { Observed } \\
\text { VDA9926 }\end{array}$ & $\begin{array}{l}\text { Percentage } \\
\text { of residue } \\
\text { (Model 1) }\end{array}$ & $\begin{array}{l}\text { Percentage } \\
\text { of residue } \\
\text { (Model 2) }\end{array}$ & $\begin{array}{l}\text { VDA9926 } \\
\text { C0 }\end{array}$ & $\begin{array}{l}\text { Calculated C1 } \\
\text { (Model 3) }\end{array}$ & $\begin{array}{l}\text { Observed } \\
\text { VDA9927 }\end{array}$ & $\begin{array}{l}\text { Percentage } \\
\text { of residue }\end{array}$ \\
\hline $\mathrm{Rb}$ & 85 & 113 & 118 & 101 & -12 & -16 & 101 & 113 & 122 & 8 \\
\hline $\mathrm{Sr}$ & 773 & 587 & 505 & 524 & -12 & 4 & 524 & 308 & 274 & -13 \\
\hline $\mathrm{Ba}$ & 1835 & 2452 & 2526 & 2116 & -16 & -19 & 2116 & 1735 & 1442 & -20 \\
\hline $\mathrm{Ta}$ & 1.7 & 1.9 & 1.9 & 1.6 & -18 & -18 & 1.6 & 1.3 & 0.9 & -43 \\
\hline $\mathrm{Ce}$ & 293 & 271 & 290 & 237 & -25 & -33 & 237 & 162 & 156 & -4 \\
\hline $\mathrm{Sm}$ & 27.4 & 18 & 21 & 22.5 & 11 & -2 & 22.5 & 12 & 12.9 & 7 \\
\hline $\mathrm{Eu}$ & 6.5 & 5.0 & 5.5 & 4.8 & -3 & -15 & 4.8 & 3.5 & 3.1 & -12 \\
\hline $\mathrm{Tb}$ & 3.2 & 2.4 & 2.6 & 2.7 & 16 & 10 & 2.7 & 1.6 & 1.3 & -16 \\
\hline $\mathrm{Yb}$ & 6.8 & 6.0 & 6.7 & 6.1 & 16 & 7 & 6.1 & 5.3 & 3.6 & -15 \\
\hline
\end{tabular}

Table 7. Results of trace elements modelling

Three possible models are obtained by major elements modelling for stage 2 . The fractionating minerals are plagioclase, hornblende, magnetite, ilmenite and apatite for Model 1 , the same minerals plus biotite in Model 2 and plus biotite and clinopyroxene in Model 3. The sums of the squared residual are low (Table 6) and the percentage of crystallisation is nearly 32\% for Models 1 and 2 and 37\% for Model 3. Models 1 and 2 are not favoured as clinopyroxene is still stable when biotite appears experimentally at 4 kbar (Bogaerts et al., 2001). Moreover, trace elements modelling show that an important amount of biotite is needed to lower the $\mathrm{Ba}$ content in the residual melt. The proportion of subtracted zircon is higher $(0.26 \%)$ than in stage 1 . A small amount of allanite $(0.1 \%)$ is also needed to get LREE values of the calculated melt close to values of the natural sample (VDA9927). This mineral has been reported in the Lyngdal granodiorite and is thus justified as a fractionating phase in the modelling.

Major and trace elements thus show that the Lyngdal and Tranevåg granitoids belong to the same liquid line of descent. However, the slight differences in $\mathrm{Sr}_{\mathrm{i}}$ indicate that the two massifs are not strictly comagmatic. 


\subsubsection{Origin of the Lyngdal and Tranevåg granitoids}

The Lyngdal granodiorite has already been investigated by $\mathrm{Pb}-\mathrm{Nd}-\mathrm{Sr}$ isotopic studies but without an associated geochemical investigation by major and trace elements (Weis, 1986; Demaiffe et al., 1986; Pedersen and Falkum, 1975 and Menuge, 1988) and related petrographical observations. Duchesne and Demaiffe (1978) suggested that the Lyngdal granodiorite could have a genetic link with the anorthosites and would represent residual liquid from the differentiation of a jotunitic magma. Demaiffe et al. (1986) and Weis (1986) stressed that if an origin by partial melting of the crust is a viable hypothesis, a mantle origin is also possible provided that some contamination occurs. Menuge (1988) favoured the latter hypothesis and proposed that the Lyngdal granodiorite is a residual liquid derived from the crystallisation of a mixture of mantle and crustal melts.

The hydrous and oxidised character of the Lyngdal granodiorite (Bogaerts et al., 2001) contrasts with the dry and reduced status inferred for the Rogaland Anorthosite-MangeriteCharnockite suite ( Vander Auwera and Longhi, 1994). This suggests that, though coeval with the anorthosites, the Lyngdal and Tranevåg granitoids cannot be a residual liquid from the differentiation of a jotunitic magma, as previously suggested by Duchesne and Demaiffe $\underline{(1978)}$.

As seen above, the Lyngdal and Tranevåg trend (from 56.34 to 71.69 wt.\% $\mathrm{SiO}_{2}$ ) is part of the HBG trend (Vander Auwera et al., 2003) that ranges from gabbronorites $\left(50 \mathrm{wt} . \% \mathrm{SiO}_{2}\right)$ to granites $\left(76.6\right.$ wt.\% $\left.\mathrm{SiO}_{2}\right)$. Vander Auwera et al. (2003) suggest that the HBG granitoids are derived from gabbronorites by fractional crystallisation with some assimilation. These authors proposed that melting of potassic amphibolites or of an enriched mantle are suitable processes to give gabbronoritic magmas. The small differences in $\mathrm{Sr}_{\mathrm{i}}$ between Lyngdal and Tranevåg could be explained by two distinct batches of gabbros evolving along similar liquid line of descent.

\subsubsection{The Red Granite}

We have only a limited number of Red Granite samples; hence the following interpretation will be only qualitative. Although the Red Granite is at the end of the Lyngdal-Tranevåg trend for the major elements, it cannot be considered as being an end product of the liquid line of descent modelled above. Indeed, the $X_{\mathrm{Fe}}$ is lower while LREE, Th, Sr, Rb from the Red Granite are above the Lyngdal-Tranevåg trend (see Section 5.1). The presence of fluorite as well as the very high $\mathrm{F}$ content in biotite $(>5 \mathrm{wt} . \%)$ implies a high $f_{\mathrm{F}}$. The origin of fluorite in granitic magmas is subject to debate: some authors consider it as crystallising from a fluid and others from the melt itself (e.g. Collins et al., 1982 and King et al., 1997). The petrographical observations indicate a hydrothermal alteration episode (sericitised plagioclase and chloritised biotite) but except for the geochemical differences described above, the trace element pattern of the Red Granite is similar to Lyngdal-Tranevåg one. Let us note that VDA9920 sample, which belongs to the Tranevåg massif, has the same geochemical particularities than the Red Granite except that its ferromagnesian minerals are not altered. A hydrothermal alteration episode is then probably not responsible for the geochemical particularity of the Red Granite. The lowering of $\varepsilon_{\mathrm{Nd}}$ for a constant $\mathrm{Sr}_{\mathrm{i}}$, from sample VDA9920 to the Red Granite, could be achieved by contamination with a Rb-depleted lower crust of a magma similar to the quartz monzodiorite (VDA9925) from the Lyngdal-Tranevåg trend. A LILE-depleted crust as contaminant is, however, untenable due to the higher $\mathrm{Rb}$ and Th content in the Red Granite 
than in granites from the Lyngdal-Tranevåg trend. The higher LREE-Th-Rb-Sr and lower $\varepsilon$ $\mathrm{Nd}$ content in the Red Granite is probably due to a different initial magma composition.

\section{Conclusions}

The Lyngdal granodiorite, and associated plutons (Tranevåg and the Red Granite) are ferropotassic A-type granitoids and belong to the post-collisional HBG suite of Southern Norway (see Vander Auwera et al., 2003). The HBG suite is penecontemporaneous with the AMC suite of Rogaland, the Lyngdal plutons being spatially associated with the AMC suite. This kind of association is similar to the rapakivi granitoids associated with anorthosite massifs and charnockites (the AMCG complexes: Emslie, 1991). This study underlines the geochemical similarities between the Lyngdal plutons and the rapakivi granitoids. However, notable differences exist between the Lyngdal plutons and the rapakivi granitoids from AMCG complexes:

1. absence of rapakivi texture in the Lyngdal plutons and the whole HBG suite;

2. oxidised $(\mathrm{NNO} / \mathrm{NNO}+1)$ and water-rich $(6 \mathrm{wt} . \%)$ nature of the Lyngdal granodiorite (Bogaerts et al., 2001) contrasting with the dry and reduced nature $(<\mathrm{NNO}-1)$ inferred for the rapakivi granitoids associated with anorthosite massifs;

3. The Lyngdal plutons (except the Red Granite) form a continuous trend from quartz monzodiorite to granite (56-72 wt.\% $\mathrm{SiO}_{2}$ : called the Lyngdal-Tranevåg trend) and the intermediate composition (granodiorite) dominates. The Lyngdal pluton is indeed a huge masse of homogeneous granodiorite $\left(\mathrm{SiO}_{2}\right.$ ranges between 60 and $\left.65 \mathrm{wt} . \%\right)$, while the rapakivi are dominantly granitic in composition (>65 wt.\%).

With $\mathrm{Sr}-\mathrm{Nd}$ isotopes and major and trace elements modelling, our study shows that the granites of the Lyngdal-Tranevåg trend are derived by fractional crystallisation (without significant crustal assimilation) from the quartz monzodiorites. These results can be extended to the whole HBG suite. Moreover, the quartz monzodiorites could be derived by the crystallisation of gabbronorites (Vander Auwera et al., 2003). The observation of mingling between gabbronorites and granitoids (in Lyngdal and Tranevåg) favour this process. This contrasts with the model proposed for the rapakivi granitoids that are considered as primary crustal melts (e.g. Rämö and Haapala, 1995 and references therein) and with the model generally proposed for AMCG complexes. Such complexes are indeed often considered as bimodal (e.g. Emslie et al., 1994): anorthosites and related rocks forming the basic part of the association and rapakivi granites and charnockites forming the acid part. In this model, charnockites and rapakivi granites are considered as similar, reduced and anhydrous magmas. In Southern Norway, however, this study and Bogaerts et al. (2001) show that the hydrous and oxidised character of the Lyngdal granodiorite (extended to the whole HBG suite: Vander Auwera et al., 2003) contrasts with the dry and reduced status inferred for the charnockites of the AMC suite. Moreover, both kind of granitoids are end-members of continuous liquid lines of descent from mafic to felsic magmas and this magmatism is definitely not bimodal.

\section{Acknowledgements}

We would like to thank G. Bologne, J.-P. Cullus and G. Delhaze for help with the chemical analyses and sample preparations. The microprobe analyses were performed under the supervision of J. Wauthier (UCL) and O. Rouer (ISTO). This paper benefits from the 
reviewing of $\mathrm{H}$. Martin and G. Poli. This work was funded by the Belgian Fund for Joint Research. M. Bogaerts is 'Aspirant' of this Foundation.

\section{References}

- $\quad$ Anderson, J.L., 1983. Proterozoic anorogenic granite plutonism of North America. In: Medaris L.G., Byers C.W.J., Mickelson D.M., Shanks W.C. (Eds.), Proterozoic Geology: Selected Papers from an International Proterozoic Symposium. Geological Society of America Memoir, pp. 133-154.

- Anderson, J.L. and Bender, E.E., 1989. Nature and origin of Proterozoic A-type granitic magmatism in the southwestern United States of America. Lithos 23, pp. 1952.

- $\quad$ Anderson, J.L. and Cullers, R.L., 1978. Geochemistry and evolution of the Wolf River batholith, a late Precambrian rapakivi massif in North Wisconsin, USA. Precambrian Res. 7, pp. 287-324.

- $\quad$ Anderson, J.L., Morrison, J., 1992. The role of anorogenic granites in the Proterozoic crustal development of North America. In: Condie K.C. (Ed.), Proterozoic Crustal Evolution. Developments in Precambrian Geology. Elsevier, Amsterdam, pp. 263291.

- $\quad$ Anderson, J.L. and Smith, D.R., 1995. The effects of temperature and $f \mathrm{O}_{2}$ on the Alin-hornblende barometer. Am. Mineral. 80, pp. 549-559.

- Bacon, C.R. and Druitt, T.H., 1988. Compositional evolution of the zoned calcalkaline magma chamber of Mount Mazama, Crater Lake, Oregon. Contrib. Mineral. Petrol. 98, pp. 224-256.

- Barbarin, B. and Didier, J., 1992. Genesis and evolution of mafic microgranular enclaves through various types of interaction between coexisting felsic and mafic magmas. Transactions of the Royal Society of Edinburgh: Earth Sci. 83, pp. 145-153.

- Barker, F., Wones, D.R. and Desborough, G.A., 1975. The Pikes Peak Batholith, Colorado Front Range, and a model for the origin of the gabbro-anorthosite-syenitepotassic granite suite. Precambrian Res. 2, pp. 97-160.

- Beard, J.S., Lofgren, G.E., Sinha, A.K. and Tollo, R.P., 1994. Partial melting of apatite-bearing charnockite, granulite, and diorite: melt compositions, restite mineralogy, and petrological implications. J. Geophy. Res. 99, pp. 21591-21603.

- $\quad$ Bingen, B., 1989. Geochemistry of Sveconorwegian augen gneisses from SW Norway at the amphibolite-granulite facies transition. Norsk Geologisk Tidsskrift 69, pp. 177189

- $\quad$ Bingen, B., Birkeland, A., Nordgulen, Ø. and Sigmond, E.M.O., 2001. Correlation of supracrustal sequences and origin of terranes in the Sveconorwegian orogen of SW Scandinavia: SIMS data on zircon in clastic metasediments. Precambrian Res. 108, pp. 293-318.

- Bingen, B., Stein, H., 2001. Re-Os dating of the Ørsdalen W-Mo district in Rogaland, $\mathrm{S}$ Norway, and its relationship to Sveconrowegian high-grade metamorphism. Abstracts-GEODE field workshop 8-12th July 2001 on ilmenite deposits in the Rogaland anorthosite province, SW Norway. NGU Report $n^{\circ}$. 2001.042, pp. 15-18.

- Bingen, B. and van Breemen, O., 1998. Tectonic regimes and terrane boundaries in the high-grade Sveconorwegian belt of $\mathrm{SW}$ Norway, inferred from $\mathrm{U}-\mathrm{Pb}$ zircon geochronology and geochemical signature of augen gneiss suites. J.Geol. Soc. (London) 155, pp. 143-154. 
- Bingen, B. and van Breemen, O., 1998. U-Pb monazite ages in amphibolite- to granulite-facies orthogneiss reflect hydrous mineral breakdown reactions: Sveconorwegian Province of SW Norway. Contrib. Mineral. Petrol. 132, pp. 336353.

- Bogaerts, M., Scaillet, B. and Vander Auwera, J., 2001. Experimental determination of phase equilibria of the Lyngdal granodiorite (Southern Norway). J. Conference Abstr. 6, p. 770.

- Bologne, G., Duchesne, J.C., 1991. Analyse des roches silicatées par spectrométrie de fluorescence $X$ : précision et exactitude. Service Géologique de Belgique. Professional Paper, 249.

- $\quad$ Brooks, C.K., Henderson, P. and Rønsbo, J.G., 1981. Rare-earth partition between allanite and glass in the obsidian of Sandy Braes, Northern Ireland. Mineral. Magazine 44, pp. 157-160.

- Chappell, B.W., White, A.J.R. and Wyborn, D., 1987. The importance of residual source material (restite) in granite petrogenesis. J. Petrol. 28, pp. 1111-1138.

- Chauvel, C. and Blichert-Toft, J., 2001. A hafnium isotope and trace element perspective on melting of the depleted mantle. E. Planet. Sci. Lett. 190, pp. 137-151.

- Clemens, J.D., Holloway, J.R. and White, A.J.R., 1986. Origin of an A-type granite: experimental constraints. Am. Mineral. 71, pp. 317-324.

- Collins, W.J., Beams, S.D., White, A.J.R. and Chappell, B.W., 1982. Nature and origin of A-type granites with particular reference to southeastern Australia. Contrib. Mineral. Petrol. 80, pp. 189-200.

- Creaser, R.A., Price, R.C. and Wormald, R.J., 1991. A-type granites revisited: assessment of a residual-source model. Geology 19, pp. 163-166.

- Dall'Agnol, R., Costi, H.T., da, S., Leite, A.A., de Magalhães, M.S. and Teixeira, N.P., 1999. Rapakivi granites from Brazil and adjacent areas. Precambrian Res. 95, pp. 9-39.

- Dall'Agnol, R., Rämö, O.T., de Magalhães, M.S. and Macambira, M.J.B., 1999. Petrology of the anorogenic, oxidised Jamon and Musa granites, Amazonian Craton: implications for the genesis of Proterozoic A-type granites. Lithos 46, pp. 431-462.

- Dall'Agnol, R., Scaillet, B. and Pichavant, M., 1999. An experimental study of a lower Proterozoic A-type granite from the Eastern Amazonian Craton, Brazil. J. Petrol. 40, pp. 1673-1698.

- Debon, F. and Le Fort, P., 1988. A cationic classification of common plutonic rocks and their magmatic associations: principles, method, applications. Bulletin de Minéralogie 111, pp. 493-510.

- Demaiffe, D., Bingen, B., Wertz, P. and Hertogen, J., 1990. Geochemistry of the Lyngdal hyperites (S.W. Norway): comparison with the monzonorites associated with the Rogaland Anorthosite Complex. Lithos 24, pp. 237-250.

- Demaiffe, D., Weis, D., Michot, J. and Duchesne, J.-C., 1986. Isotopic constraints on the genesis of the anorthosite suite of rocks. Chem. Geol. 57, pp. 167-179.

- DePaolo, D.J., 1981. Trace elements and isotopic effects of combined wallrock assimilation and fractional crystallization. Earth Planet. Sci. Lett. 53, pp. 189-202.

- Dodge, F.C.W. and Kistler, R.W., 1990. Some additional observations on inclusions in the granitic rocks of the Sierra Nevada. J. Geophys. Res. 95, pp. 17841-17848.

- Duchesne, J.-C., Berza, T., Liégeois, J.-P. and Vander Auwera, J., 1998. Shoshonitic liquid line of descent from diorite to granite: the late Precambrian post-collisional Tismana pluton (South Carpathians, Romania). Lithos 45, pp. 281-303. 
- Duchesne, J.-C. and Demaiffe, D., 1978. Trace elements and anorthosite genesis. Earth Planet. Sci. Lett. 38, pp. 249-272.

- Duchesne, J.-C., Liégeois, J.-P., Vander Auwera, J. and Longhi, J., 1999. The crustal tongue melting model and the origin of massive anorthosites. Terra Nova 11, pp. 100105.

- Eberz, G.W., Nicholls, I.A., Maas, R., McCulloch, M.T. and Whitford, D.J., 1990. The Nd- and Sr-isotopic composition of I-type microgranitoid enclaves and their host rocks from the Swifts Creek Pluton, southeast Australia. Chem. Geol. 85, pp. 119-134.

- Eklund, O., Fröjdö, S. and Lindberg, B., 1994. Magma mixing, the petrogenetic link between anorthositic suites and rapakivi granites, Åland, SW Finland. Mineral. Petrol. 50, pp. 3-19.

- Emslie, R.F., 1991. Granitoids of rapakivi granite-anorthosite and related associations. Precambrian Res. 51, pp. 173-192.

- Emslie, R.F., Hamilton, M.A. and Thiérault, R.J., 1994. Petrogenesis of a MidProterozoic Anorthosite-Mangerite-Charnockite-Granite (AMCG) complex: isotopic and chemical evidence from the Nain plutonic suite. J. Geol. 103, pp. 539-558.

- Emslie, R.F. and Stirling, J.A.R., 1993. Rapakivi and related granitoids of the Nain plutonic suite: geochemistry, mineral assemblages and fluid equilibria. Can. Mineral. 31, pp. 821-847.

- Ewart, A. and Griffin, W.L., 1994. Application of proton-microprobe data to traceelement partitioning in volcanic rocks. Chem. Geol. 117, pp. 251-284. Abstract

- Falkum, T., 1982. Geologisk kart over Norge, beggrunnskart Mandal. Norges geologiske undersøkelse.

- $\quad$ Falkum, T., Wilson, J.R., Petersen, J.S. and Zimmermann, H.D., 1979. The intrusive granites of the Farsund area, south Norway: their interrelations and relations with the Precambrian metamorphic envelope. Norsk Geologisk Tidsskrift 59, pp. 125-139.

- Feeley, T.C. and Davidson, J.P., 1994. Petrology of calc-alkaline lavas at Volcan Ollagüe and the origin of compositional diversity at Central Andean Stratovolcanoes. J. Petrol. 35, pp. 1295-1340.

- Fourcade, S. and Allègre, C.J., 1981. Trace elements behaviour in granite genesis: a case study, the calc-alkaline plutonic association from the Quérigut complex (Pyrénées, France). Contrib. Mineral. Petrol. 76, pp. 177-195. Frost, C.D. and Frost, B.R., 1997. Reduced rapakivi-type granites: the tholeiite connection. Geology 25, pp. 647-650.

- $\quad$ Frost, C.D., Frost, B.R., Chamberlain, K.R. and Edwards, B.R., 1999. Petrogenesis of the $1.43 \mathrm{Ga}$ Sherman Batholith, SE Wyoming, USA: a reduced, rapakivi-type anorogenic granite. J. Petrol. 40, pp. 1771-1802.

- Goldstein, S.L., O’Nions, R.K. and Hamilton, P.J., 1984. A Sm-Nd isotopic study of atmospheric dusts and particulates from major river systems. Earth Planet. Sci. Lett. 70, pp. 221-236.

- Haapala, I., Rämö, O.T., 1990. Petrogenesis of the Proterozoic rapakivi granites of Finland. In: Stein H.J., Hannah J.L. (Eds.), Ore-bearing granite systems, petrogenesis and mineralizing processes. Geological Society of America Special Paper, pp. 275286.

- Haapala, I. and Rämö, O.T., 1992. Tectonic setting and origin of the Proterozoic rapakivi granites of southeastern Fennoscandia. Transactions of the Royal Society of Edinburgh: Earth Sci. 83, pp. 165-171.

- Higushi, H. and Nagasawa, H., 1969. Partition of trace elements between rockforming minerals and the host volcanic rocks. Earth Planet. Sci. Lett. 7, pp. 281-287. 
- Holland, T.J., Babu, E.V. and Waters, D.J., 1996. Phase relations of osumilite and dehydration melting in pelitic rocks: a simple thermodynamic model for the KFMASH system. Contrib. Mineral. Petrol. 124, pp. 383-394.

- Huppert, H.E. and Sparks, R.S.J., 1988. The generation of granitic magmas by intrusion of basalt into the crust. J. Petrol. 29, pp. 599-624.

- Jacobsen, S.B. and Wasseburg, G.J., 1980. Sm-Nd isotopic evolution of chondrites. Earth Planet. Sci. Lett. 50, pp. 139-155.

- Jansen, B., Blok, A., Scheelings, M., 1985. Geothermometry and geobarometry in Rogaland and preliminary results from the Bamble area, south Norway. In: Tobi A.C., Touret J. (Eds.), The Deep Proterozoic Crust in the North Atlantic Provinces. NATO Advanced Study Institutes Series, Reidel, pp. 499-517.

- Johnson, M.C. and Rutherford, M.J., 1989. Experimental calibration of the aluminium-in-hornblende geobarometer with application to Long Valley caldera (California) volcanic rocks. Geology 17, pp. 837-841.

- $\quad$ King, P.L., White, A.J.R., Chappell, B.W. and Allen, C.M., 1997. Characterization and origin of aluminous A-type granites from the Lachlan Fold Belt, Southeastern Australia. J. Petrol. 38, pp. 371-391. Abstract-GEOBASE

- $\quad$ Leake, B.E., 1978. Nomenclature of amphiboles. Can. Mineral. 16, pp. 501-520.

- Liégeois, J.-P., 1998. Some words on the post-collisional magmatism. Lithos 45.

- Liégeois, J.-P., Black, R., 1987. Alkaline magmatism subsequent to collision in the Pan-African belt of the Adrar des Iforas. In: Fitton J.G., Upton B.G.J. (Eds.), Alkaline Igneous Rocks. The Geological Society, Blackwell, Oxford, pp. 381-401.

- Liégeois, J.-P., Navez, J., Hertogen, J. and Black, R., 1998. Contrasting origin of postcollisional high-K calc-alkaline and shoshonitic versus alkaline and peralkaline granitoids. The use of slidind normalization. Lithos 45, pp. 1-28.

- Loiselle, M.C. and Wones, D.R., 1979. Characteristics and origin of anorogenic granites. Geol. Soc. Am. Abstr. 11, p. 468.

- Longhi, J., Vander Auwera, J., Fram, M.S. and Duchesne, J.-C., 1999. Some phase equilibrium constraints on the origin of Proterozoic (massif) anorthosites and related rocks. J. Petrol. 40, pp. 339-362.

- Ludwig, K.R., 2001. User's manual for Isoplot/Ex version 2.49, a geochronological toolkit for Microsoft Excel. Berkeley Geochronology Center Special Publication, Berkeley, USA.

- Mahood, G. and Hildreth, W., 1983. Large partition coefficients for trace elements in high-silica rhyolites. Geochimica et Cosmochimica Acta 47, pp. 11-30.

- Martin, H., 1987. Petrogenesis of Archaen trondhjemites, tonalites, and granodiorites from Eastern Finland: major and trace element geochemistry. J. Petrol. 28 5, pp. 921953.

- Menuge, J.F., 1988. The petrogenesis of massif anorthosites: a Nd and Sr isotopic investigation of the Proterozoic of Rogaland/Vest-Agder, SW Norway. Contrib. Mineral. Petrol. 98, pp. 363-373.

- Mingeot, S., 2000. Le Granite Rouge et le granite de Tranevåg: pétrologie et géochimie comparée avec la granodiorite de Lyngdal (Norvège méridionale), Université de Liège, $45 \mathrm{pp}$.

- Nagasawa, H., 1970. Rare earth concentrations in zircons and apatites and their host dacites and granites. Earth Planet. Sci. Lett. 9, pp. 359-364.

- Nelson, B.K. and DePaolo, D.J., 1985. Rapid production of continental crust 1.7 to 1.9 b.y. ago: $\mathrm{Nd}$ isotopic evidence from the basement of the North American midcontinent. Geol. Soc. Am. Bull. 96, pp. 746-754. 
- $\quad$ Pasteels, P., Demaiffe, D. and Michot, J., 1979. U-Pb and Rb-Sr geochronology of the eastern part of the South Rogaland igneous complex, Southern Norway. Lithos 12, pp. 199-208.

- $\quad$ Peccerillo, R. and Taylor, S.R., 1976. Geochemistry of Eocene calc-alkaline volcanic rocks from the Kastamonu area, northern Turkey. Contrib. Mineral. Petrol. 58, pp. 63-81.

- Pedersen, S. and Falkum, T., 1975. Rb-Sr isochrons for the granitic plutons around Farsund, Southern Norway. Chem. Geol. 15, pp. 97-101.

- $\underline{\text { Rämö}}$, O.T. and Haapala, I., 1995. One hundred years of rapakivi granite. Mineral. Petrol. 52, pp. 129-185.

- Rapp, R.P. and Watson, E.B., 1995. Dehydration melting of metabasalt at 8-32 kbar: implications for continental growth and crust-mantle recycling. J. Petrol. 36, pp. 891931.

- $\quad$ Rickwood, P.C., 1989. Boundary lines within petrologic diagrams which use oxides of major and minor elements. Lithos 22, pp. 247-264.

- $\quad$ Roberts, M.P. and Clemens, J.D., 1993. Origin of high-potassium, calc-alkaline, I-type granitoids. Geology 21, pp. 825-828.

- Salonsaari, P.T. and Haapala, I., 1994. The Jaala-Iitti Rapakivi complex. An example of bimodal magmatism and hybridization in the Wiborg rapakivi batholith, southeastern Finland. Mineral. Petrol. 50, pp. 21-34.

- Schärer, U., Wilmart, E. and Duchesne, J.-C., 1996. The short duration and anorogenic character of anorthosite magmatism: U-Pb dating of the Rogaland complex, Norway. Earth Planet. Sci. Lett. 139, pp. 335-350.

- Schmidt, M.W., 1992. Amphibole composition in tonalite as a function of pressure: an experimental calibration of the Al-in-hornblende barometer. Contrib. Mineral. Petrol. 110, pp. 304-310.

- Steiger, R.H. and Jäger, E., 1977. Subcommission on geochronology: convention on the use of decay constants in geo- and cosmochronology. Earth Planet. Sci. Lett. 36, pp. 359-362.

- Sun, S.S., McDonough, W.F., 1989. Chemical and isotopic systematics of oceanic basalts: implications for mantle composition and processes. In: Saunders A.D., Norry M.J. (Eds.), Magmatism in the Ocean Basins. Geological Society, London, Special Publication, pp. 313-345.

- Tack, L., Liégeois, J.P., Deblond, A. and Duchesne, J.C., 1994. Kibaran A-type granitoids and mafic rocks generated by two mantle sources in a late orogenic setting (Burundi). Precambrian Res. 68, pp. 323-356.

- Turner, S.P., Foden, J.D. and Morrison, R.S., 1992. Derivation of some A-type magmas by fractionation of basaltic magma: an example from the Padthaway Ridge, South Australia. Lithos 28, pp. 151-179.

- van Marcke de Lummen, G. and Vander Auwera, J., 1990. Petrogenesis of the Traversella diorite (Piemont, Italy): a major- and trace-elements and isotopic $(\mathrm{O}, \mathrm{Sr})$ model. Lithos 24, pp. 121-136.

- $\quad$ Vander Auwera, J., Bogaerts, M., Liégeois, J.-P., Demaiffe, D., Wilmart, E., Bolle, O., Duchesne, J.-C., 2003. Derivation of the 1.0-0.9 Ga ferro-potassic A-type granitoids of Southern Norway by extreme differentiation from basic liquids. Precambrian Res. 124, 107-148.

- $\quad$ Vander Auwera, J., Bologne, G., Roelandts, I. and Duchesne, J.-C., 1998. Inductively coupled plasma-mass spectrometric (ICP-MS) analysis of silicate rocks and minerals. Geologica Belgica 1, pp. 49-53. 
- Vander Auwera, J. and Longhi, J., 1994. Experimental study of a jotunite (hypersthene monzodiorite): constraints on the parent magma composition and crystallization conditions ( $\mathrm{P}, \mathrm{T}, f \mathrm{O}_{2}$ ) of the Bjerkreim-Sokndal layered intrusion (Norway). Contrib. Mineral. Petrol. 118, pp. 60-78.

- $\quad$ Vander Auwera, J., Longhi, J. and Duchesne, J.-C., 1998. A liquid line of descent of the jotunite (hypersthene monzodiorite) suite. J. Petrol. 39, pp. 439-468.

- Vernon, R.H., 1991. Interpretation of microstructures of microgranitoid enclaves. In: Didier J., Barbarin B. (Eds.), Enclaves and Granite Petrology. Developments in Petrology, pp. 277-291.

- Weis, D., 1986. Genetic implications of Pb isotope geochemistry in the Rogaland anorthositic complex (southwest Norway). Chem. Geol. 57, pp. 181-199

- Whalen, J.B., Currie, K.L. and Chappell, B.W., 1987. A-type granites: geochemical characteristics, discrimination and petrogenesis. Contrib. Mineral. Petrol. 95, pp. 407419.

- White, A.J.R. and Chappell, B.W., 1977. Ultrametamorphism and granitoid genesis. Tectonophysics 43, pp. 7-22.

- Wones, D.R., 1989. Significance of the assemblage titanite + magnetite + quartz in granitic rocks. Am. Mineral. 74, pp. 744-749. 